\title{
SOME FACTORS AFFECTING THE AXIAL STATIC BEHAVIOR OF HIGH STRENGTH SHORT REINFORCED CONCRETE COLUMNS-THEORETICAL APPROACH
}

\section{Abdel Rahman M. Ahmed, Khairy Hassan Abdel kareem, and Lamiaa K. Idriss}

Civil Engineering Department, faculty of Engineering, Assuit University

(Received July 9, 2007 Accepted August 15, 2007)

In this study, non-linear three dimensional finite element model was utilized to study the confinement of high strength reinforced concrete short columns under axial static loading. The accuracy of the model was verified experimentally in Japan. The parameters affecting the degree of confinement of columns are: grade and quality of used concrete, grade and quality of used main longitudinal reinforcement, presence of longitudinal reinforcement, type of acting load (static or repeated loading), and rate of loading, eccentricity of applied compressive load, slenderness ratio, end condition, concrete cover, shape and size of crosssection, presence of lateral loading, presence of shear stress on columns, confinement of concrete and its factor of efficiency, type and strength of confinement material, volumetric ratio of confining steel and confining reinforced configuration. The current research is focusing on the effect of following parameters upon the static behavior of axial short columns: shape of cross-section either circular, rectangular and square, end boundary condition (fixed-fixed, hinged-hinged, fixed-hinged and fixedfree), volumetric ratio of confinement $\rho_{s}$ as: $0,1.023 \%, 1.6225 \%$, and $2.70 \%$, and grade of concrete either, $f_{c u}=300,600,900 \mathrm{~kg} / \mathrm{cm}^{2}$. The obtained theoretical results are; the axial stress $\left(f_{c c}\right)$-axial strain $\left(\varepsilon_{c c}\right)$ relationship, the lateral stress $\left(f_{c l}\right)$-axial strain $\left(\varepsilon_{c c}\right)$ relationship, the axial stress $\left(f_{c c}\right)$-lateral strain $\left(\varepsilon_{c l}\right)$ relationship, the axial stress $\left(f_{c c}\right)$ lateral stress $\left(f_{c l}\right)$ relationship and the axial stain $\left(\varepsilon_{c c}\right)$-lateral $\operatorname{strain}\left(\varepsilon_{c l}\right)$ relationship.

From the results of the study, it was declared how the previous included parameters are affecting the axial static behavior of confined high strength R.C short columns.

For different volumetric ratios, the strength ratios $\left(f_{c c} / f_{c u}, f_{c l} / f_{c c}, f_{c l} / f_{c u}\right)$ increases with increase of volumetric ratio $\left(\rho_{s}\right)$ and the highest strength for circular columns than rectangular columns than that for square columns. Also, the strength ratios decrease with increase grade of concrete $\left(f_{\text {cu }}\right)$.

For different end condition, the highest strength ratios for square columns at (fixed-fixed) end condition than for circular columns than for square columns both at (hinged-hinged) end condition. 
KEYWORDS: High strength short column; Confinement, Axial static behavior, Longitudinal and lateral reinforcement, Non linear3D finite element, ABAQUS.

\section{NOTATION}

Ag: $\quad$ gross cross section area of column

$\mathrm{b}, \mathrm{d}$ : $\quad$ width and depth of reinforced concrete column rectangular or square section

D: diameter of reinforced concrete column of circular section

$f_{\text {cu }}$ : $\quad$ specified concrete compressive strength based on standard cylinder test (grade of concrete)

$f_{\mathrm{cc}}$ : maximum compressive strength of core concrete

$f_{\mathrm{cl}}: \quad$ maximum effective (lateral) confining stress

L: $\quad$ Column length,

$\rho_{\mathrm{s}} \%$ : volumetric ratio of transverse reinforcement

$\mu \%$ : longitudinal reinforcement ratio

$\varepsilon_{\mathrm{cc}}: \quad$ strain at maximum strength of concrete

$\varepsilon_{\mathrm{cl}}: \quad$ lateral strain at (lateral) confining stress

\section{INTRODUCTION}

High-strength concrete may offer the most cost-efficient solution for many structural design problems while providing higher strengths and improve durability. The use of HSC is particularly advantageous in compression member. For this reason, the use of HSC in columns and core walls of buildings among other applications is increasing allowing for more rapid construction by attaining higher strength at an earlier age, reducing anchorage length requirement; and higher durability. Also HSC permits early form removal, increasing the speed of construction, lower deflections due to increased modulus of elasticity, lower creep, and greater resistance to physical and chemical deterioration constitute other advantages related to improved performance (Salim et al., 1999). The use of HSC in columns leads to smaller cross sections, higher load carrying capacity, less reinforcing steel requirements, and less frame work.

The behavior of reinforced concrete columns is generally affected by some main factors as:

1. Grade and quality of concrete and main reinforcement Salim (1994),

2. Type of acting load (static and repeated loading): Salim et al. (1994),

3. Rate of loading: Salim (1994).

4. Eccentricity of applied compressive load and its deformability: Natalie (1996), Stephen (2001).

5. Confinement of concrete columns,

6. Volumetric ratio of transverse reinforcement: Salim et al. (1999).

7. Strength of confinement steel: Polat (1992), (Sugano et al., 1990).

8. Confining reinforcement spacing: Salim et al. (1999), (J. Xia et al. 1996).

9. Confinement reinforcement configuration: Li Bing et al. (2001).

10. Presence of lateral loading and it's direction: Watanabe et al. (1987). 
11. Presence of shear stress: Abdel-Fattah et al. (1989).

12. Type of confinement material: Mander et al. (1988).

13. Shape and size of cross-section: Salim et al. (1994) and

14. Slenderness ratio as well as different end condition: CEEN 219 (2002)

\section{PARAMETERS OF THE STUDY}

The current research is focusing on studying the effect of following parameters upon the static behavior of axial short columns:

- Shape of cross-section either of circular, rectangular and square,

- End boundary condition either fixed-fixed, hinged-hinged, fixed-hinged and fixed-free,

- Volumetric ratio $\left(\rho_{\mathrm{s}}\right)$ of confinement as: $0,1.023 \%, 1.6225 \%$, and $2.70 \%$, and

- Grade of concrete either, $f_{\mathrm{cu}}=300,600,900 \mathrm{~kg} / \mathrm{cm}^{2}$ ). See Figs. (1) and (2) The properties of the studied 72 columns are summarized in Tables (1), (2) and (3) taking all above referred parameters.

\section{THEORETICAL APPROACH FOR AXIALLY LOADED R.C COLUMNS:}

The modifications were based on an analytical model carried out by (Khairy Hassan, 1999). In the current study, we used finite element software called ABAQUS. To fulfill the purpose of the above mentioned study 72 R.C short columns were analyzed using the ABAQUS model.

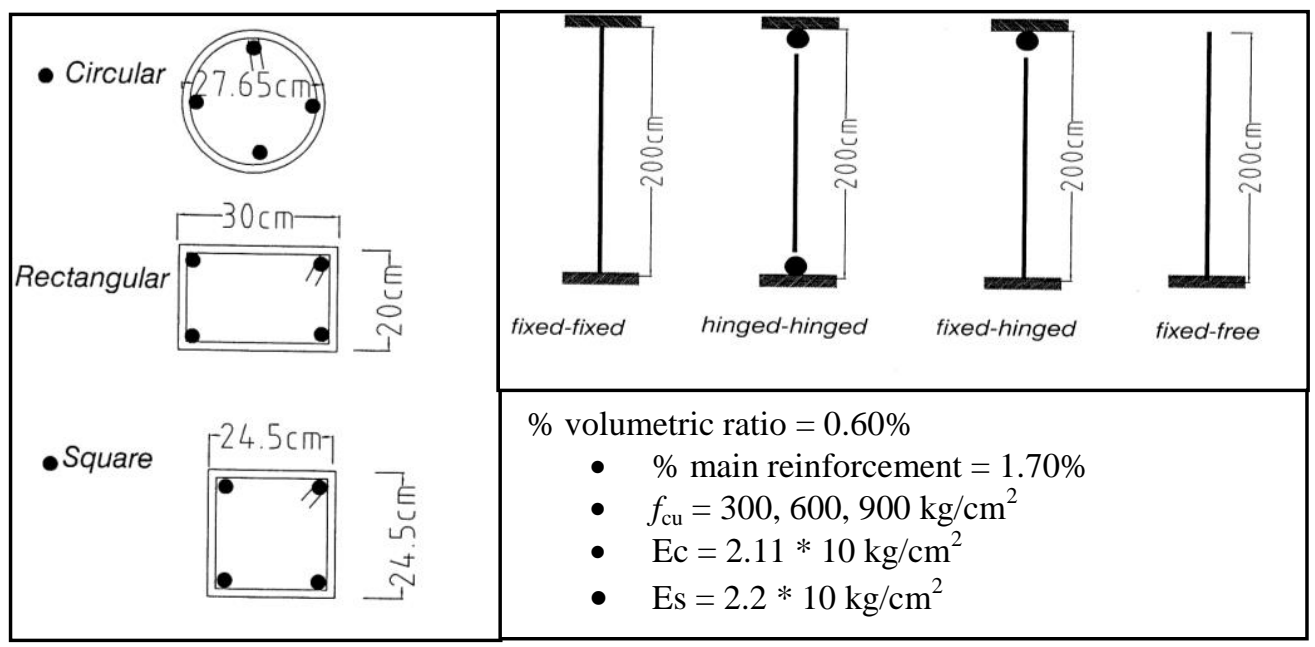

Fig.1: End boundary condition

\section{THE OBTAINED THEORETICAL RESULTS}

The obtained theoretical results one can evaluate the following relationship for all studied parameters; The axial stress $\left(f_{\mathrm{cc}}\right)$-axial strain $\left(\varepsilon_{\mathrm{cc}}\right)$ relationship, The lateral stress $\left(f_{\mathrm{cl}}\right)$ - axial strain $\left(\varepsilon_{\mathrm{cc}}\right)$ relationship, The axial stress $\left(f_{\mathrm{cc}}\right)$-lateral strain $\left(\varepsilon_{\mathrm{cl}}\right)$ relationship, The axial stress $\left(f_{\mathrm{cc}}\right)$-later stress $\left(f_{\mathrm{cl}}\right)$ relationship and The axial stain 
$\left(\varepsilon_{\mathrm{cc}}\right)$-lateral strain $\left(\varepsilon_{\mathrm{cl}}\right)$ relationship. Tables (1), (2) and (3) summarizes the obtained theoretical results of both maximum stresses and strains for the studied columns.

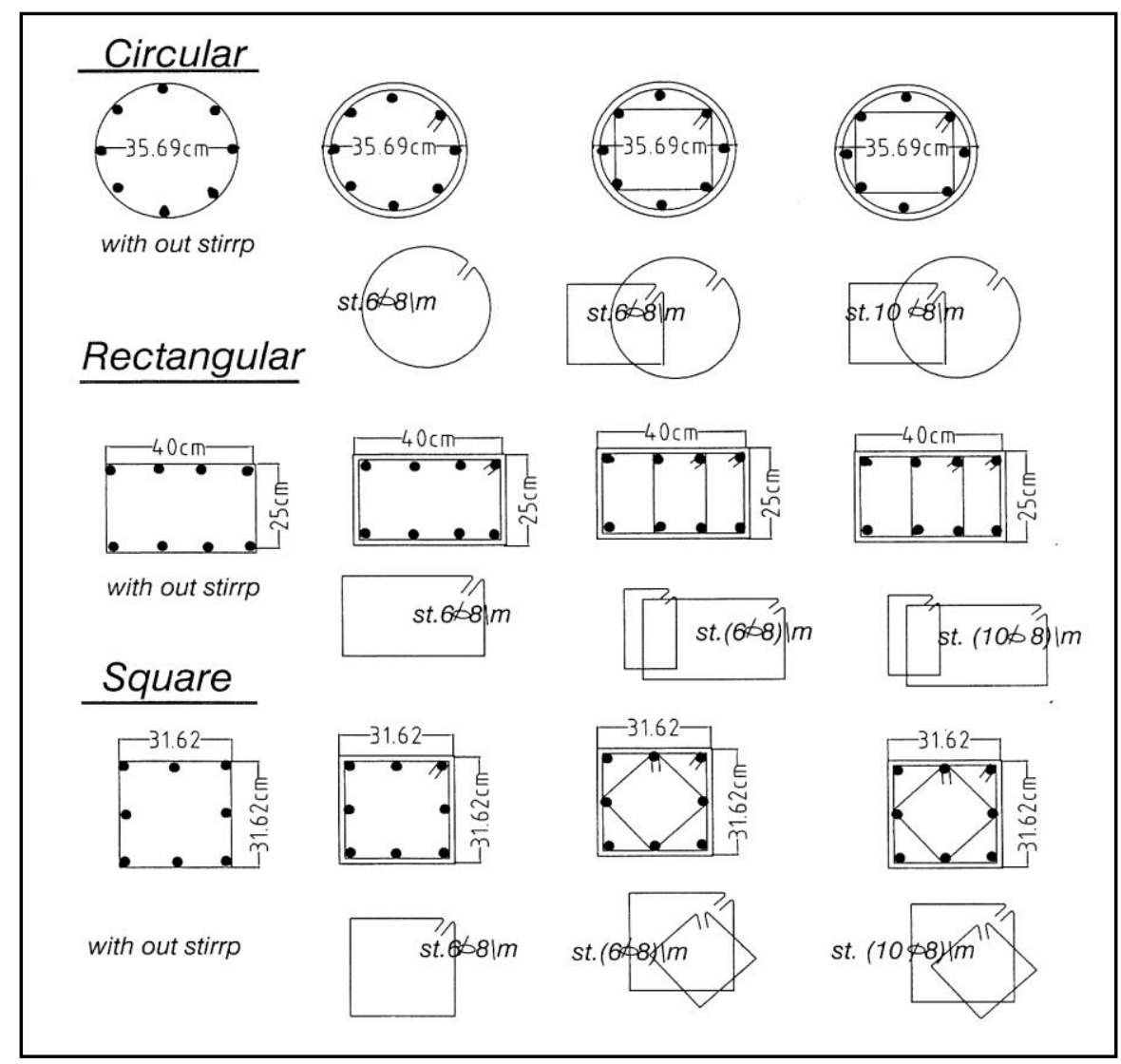

Fig.(2): Confining reinforcement configuration.

\section{Axial stress $\left(f_{\mathrm{cc}}\right)$ - axial strain $\left(\varepsilon_{\mathrm{cc}}\right)$ relationship}

Figures (3), (4) and (5), show samples of the obtained axial stress $\left(f_{\mathrm{cc}}\right)$-axial strain $\left(\varepsilon_{\mathrm{cc}}\right)$ relationships for circular, rectangular and square sections with constant volumetric ratio $\left(\rho_{\mathrm{s}}=0.6 \%\right)$ using different grades of concrete $\left(f_{\mathrm{cu}}=300,600,900\right.$ $\mathrm{Kg} / \mathrm{cm}^{2}$ ) for the different end conditions of columns (fixed-fixed, hinged-hinged, fixed- hinged and fixed-free). 
Table (1): Properties of Studied R.C Columns for Rectangular Section.

\begin{tabular}{|c|c|c|c|c|c|c|c|c|c|c|c|}
\hline \multirow{2}{*}{$\begin{array}{l}\text { Column } \\
\text { No. } \\
\text { designation }\end{array}$} & \multirow[b]{2}{*}{ End condition } & \multirow{2}{*}{$\begin{array}{l}\text { Shape } \\
\text { of cross } \\
\text { section }\end{array}$} & \multirow{2}{*}{$\begin{array}{l}\text { Height } \\
\text { of } \\
\text { column } \\
\text { (L)cm }\end{array}$} & \multicolumn{2}{|c|}{$\begin{array}{l}\text { Cross-section } \\
\text { dimensions }\end{array}$} & \multirow{2}{*}{$\begin{array}{c}\text { Grade of } \\
\text { used } \\
\text { concrete } \\
f_{\mathrm{cu}} \\
\mathrm{kg} / \mathrm{cm}^{2}\end{array}$} & \multicolumn{3}{|c|}{ Longitudinal reinforcement } & \multicolumn{2}{|c|}{ Transverse reinforcement } \\
\hline & & & & $\begin{array}{l}(\mathrm{b} \times \mathrm{t}) \text { or } \mathrm{D} \\
(\mathrm{cm})\end{array}$ & $\begin{array}{c}\mathrm{Ag} \\
\mathrm{Cm}^{2}\end{array}$ & & $\begin{array}{c}\text { No. of } \\
\text { bars }\end{array}$ & $\begin{array}{c}\text { Area of } \\
\text { Reinf. } \\
\mathrm{Cm}^{2}\end{array}$ & $\begin{array}{c}\% \text { of } \\
\text { Reinf. }(\mu)\end{array}$ & $\begin{array}{l}\text { No. of Ties } \\
\text { and Diameter } \\
\text { of bars }(\mathrm{mm})\end{array}$ & $\begin{array}{l}\text { Volumetri } \\
\text { c ratio } \\
\text { (ps) \% }\end{array}$ \\
\hline$\overline{\mathrm{C} 1}$ & Fixed-free & \multirow{24}{*}{ 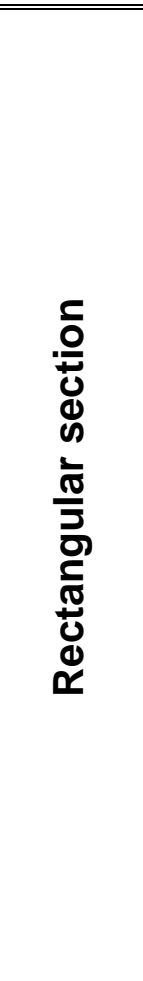 } & \multirow{24}{*}{$\begin{array}{l}\text { Ė } \\
\text { O } \\
\text { O } \\
\text { II } \\
\end{array}$} & $25 \times 40$ & 1000 & 300 & $8 \phi 16$ & 16.08 & 1.61 & 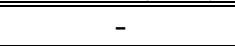 & 0 \\
\hline $\mathrm{C} 2$ & Fixed-free & & & $25 \times 40$ & 1000 & 300 & $8 \phi 16$ & 16.08 & 1.61 & $6 \phi 8$ & 1.023 \\
\hline C3 & Fixed-free & & & $25 \times 40$ & 1000 & 300 & $8 \phi 16$ & 16.08 & 1.61 & $2 \times 6 \phi 8$ & 1.625 \\
\hline $\mathrm{C} 4$ & Fixed-free & & & $25 \times 40$ & 1000 & 300 & $8 \phi 16$ & 16.08 & 1.61 & $2 \times 10 \phi 8$ & 2.7 \\
\hline C5 & Fixed-free & & & $25 \times 40$ & 1000 & 600 & $8 \phi 16$ & 16.08 & 1.61 & - & 0 \\
\hline C6 & Fixed-free & & & $25 \times 40$ & 1000 & 600 & $8 \phi 16$ & 16.08 & 1.61 & $6 \phi 8$ & 1.023 \\
\hline $\mathrm{C} 7$ & Fixed-free & & & $25 \times 40$ & 1000 & 600 & $8 \phi 16$ & 16.08 & 1.61 & $2 \times 6 \phi 8$ & 1.6225 \\
\hline $\mathrm{C} 8$ & Fixed-free & & & $25 \times 40$ & 1000 & 600 & $8 \phi 16$ & 16.08 & 1.61 & $2 \times 10 \phi 8$ & 2.7 \\
\hline C9 & Fixed-free & & & $25 \times 40$ & 1000 & 900 & $8 \phi 16$ & 16.08 & 1.61 & - & 0 \\
\hline $\mathrm{C} 10$ & Fixed-free & & & $25 \times 40$ & 1000 & 900 & $8 \phi 16$ & 16.08 & 1.61 & $6 \phi 8$ & 1.023 \\
\hline C11 & Fixed-free & & & $25 \times 40$ & 1000 & 900 & $8 \phi 16$ & 16.08 & 1.61 & $2 \times 6 \phi 8$ & 1.6225 \\
\hline $\mathrm{C} 12$ & Fixed-free & & & $25 \times 40$ & 1000 & 900 & $8 \phi 16$ & 16.08 & 1.61 & $2 \times 10 \phi 8$ & 2.7 \\
\hline C13 & Fixed-fixed & & & $20 \times 30$ & 600 & 300 & $4 \phi 18$ & 10.17 & 1.7 & $6 \phi 8$ & 0.6 \\
\hline $\mathrm{C} 14$ & Hinged-hinged & & & $20 \times 30$ & 600 & 300 & $4 \phi 18$ & 10.17 & 1.7 & $6 \phi 8$ & 0.6 \\
\hline $\mathrm{C} 15$ & Fixed-hinged & & & $20 \times 30$ & 600 & 300 & $4 \phi 18$ & 10.17 & 1.7 & $6 \phi 8$ & 0.6 \\
\hline $\mathrm{C} 16$ & Fixed-free & & & $20 \times 30$ & 600 & 300 & $4 \phi 18$ & 10.17 & 1.7 & $6 \phi 8$ & 0.6 \\
\hline C17 & Fixed-fixed & & & $20 \times 30$ & 600 & 600 & $4 \phi 18$ & 10.17 & 1.7 & $6 \phi 8$ & 0.6 \\
\hline C18 & Hinged-hinged & & & $20 \times 30$ & 600 & 600 & $4 \phi 18$ & 10.17 & 1.7 & $6 \phi 8$ & 0.6 \\
\hline C19 & Fixed-hinged & & & $20 \times 30$ & 600 & 600 & $4 \phi 18$ & 10.17 & 1.7 & $6 \phi 8$ & 0.6 \\
\hline C20 & Fixed-free & & & $20 \times 30$ & 600 & 600 & $4 \phi 18$ & 10.17 & 1.7 & $6 \phi 8$ & 0.6 \\
\hline C21 & Fixed-fixed & & & $20 \times 30$ & 600 & 900 & $4 \phi 18$ & 10.17 & 1.7 & $6 \phi 8$ & 0.6 \\
\hline C22 & Hinged-hinged & & & $20 \times 30$ & 600 & 900 & $4 \phi 18$ & 10.17 & 1.7 & $6 \phi 8$ & 0.6 \\
\hline C23 & Fixed-hinged & & & $20 \times 30$ & 600 & 900 & $4 \phi 18$ & 10.17 & 1.7 & $6 \phi 8$ & 0.6 \\
\hline C24 & Fixed-free & & & $20 \times 30$ & 600 & 900 & $4 \phi 18$ & 10.17 & 1.7 & $6 \phi 8$ & \\
\hline
\end{tabular}


Table (2): Properties of Studied R.C Columns for Circular Section.

\begin{tabular}{|c|c|c|c|c|c|c|c|c|c|c|c|}
\hline \multirow{2}{*}{$\begin{array}{c}\text { Column } \\
\text { No. } \\
\text { designation }\end{array}$} & \multirow[b]{2}{*}{ End condition } & \multirow{2}{*}{$\begin{array}{l}\text { Shape } \\
\text { of cross } \\
\text { section }\end{array}$} & \multirow{2}{*}{$\begin{array}{l}\text { Height } \\
\text { of } \\
\text { column } \\
(\mathrm{L}) \mathrm{cm}\end{array}$} & \multicolumn{2}{|c|}{$\begin{array}{c}\text { Cross-section } \\
\text { dimensions }\end{array}$} & \multirow{2}{*}{$\begin{array}{c}\text { Grade of } \\
\text { used } \\
\text { concrete } \\
f_{\mathrm{cu}} \\
\mathrm{kg} / \mathrm{cm}^{2} \\
\end{array}$} & \multicolumn{3}{|c|}{ Longitudinal reinforcement } & \multicolumn{2}{|c|}{ Transverse reinforcement } \\
\hline & & & & $\begin{array}{l}(\mathrm{b} \times \mathrm{t}) \text { or } \mathrm{D} \\
(\mathrm{cm})\end{array}$ & $\mathrm{Ag}^{2}$ & & $\begin{array}{l}\text { No. of } \\
\text { bars }\end{array}$ & $\begin{array}{l}\text { Area of } \\
\text { Reinf. } \\
\mathrm{Cm}^{2}\end{array}$ & $\begin{array}{c}\% \text { of } \\
\text { Reinf. }(\mu)\end{array}$ & $\begin{array}{l}\text { No. of Ties } \\
\text { and Diameter } \\
\text { of bars }(\mathrm{mm})\end{array}$ & $\begin{array}{l}\text { Volumetri } \\
\text { c ratio } \\
\text { ( } \mathrm{s}) \% \\
\end{array}$ \\
\hline C25 & Fixed-free & \multirow{24}{*}{ 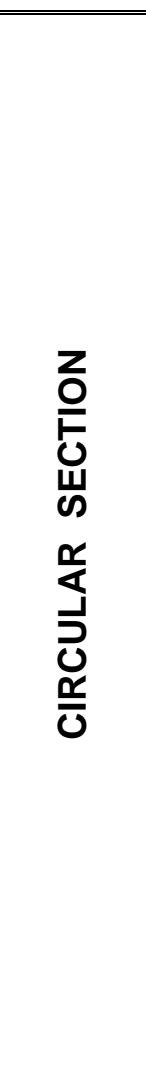 } & \multirow{24}{*}{ 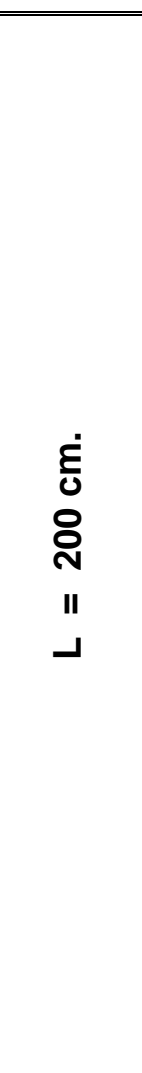 } & 35.69 & 1000 & 300 & $8 \phi 16$ & 16.08 & 1.61 & 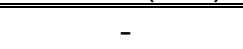 & 0 \\
\hline C26 & Fixed-free & & & 35.69 & 1000 & 300 & $8 \phi 16$ & 16.08 & 1.61 & $6 \phi 8$ & 1.023 \\
\hline C27 & Fixed-free & & & 35.69 & 1000 & 300 & $8 \phi 16$ & 16.08 & 1.61 & $2(6 \phi 8)$ & 1.6225 \\
\hline C28 & Fixed-free & & & 35.69 & 1000 & 300 & $8 \phi 16$ & 16.08 & 1.61 & $2(10 \phi 8)$ & 2.7 \\
\hline$\overline{C 29}$ & Fixed-free & & & 35.69 & $\overline{1000}$ & $\overline{6600}$ & $8 \phi 16$ & $\begin{array}{l}16.08 \\
\end{array}$ & $\overline{c 1.61}$ & $\begin{array}{c}- \\
-\end{array}$ & $\overline{00}$ \\
\hline C30 & Fixed-free & & & 35.69 & 1000 & 600 & $8 \phi 16$ & 16.08 & 1.61 & $6 \phi 8$ & 1.023 \\
\hline C31 & Fixed-free & & & 35.69 & 1000 & 600 & $8 \phi 16$ & 16.08 & 1.61 & $2(6 \phi 8)$ & 1.6225 \\
\hline C32 & Fixed-free & & & 35.69 & 1000 & 600 & $8 \phi 16$ & 16.08 & 1.61 & $2(10 \phi 8)$ & 2.7 \\
\hline C33 & Fixed-free & & & 35.69 & $\overline{c 1000}$ & 900 & $8 \phi 16$ & $\begin{array}{l}16.08 \\
\end{array}$ & $\overline{c 1.61}$ & 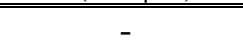 & $\overline{00}$ \\
\hline C34 & Fixed-free & & & 35.69 & 1000 & 900 & $8 \phi 16$ & 16.08 & 1.61 & $6 \phi 8$ & 1.023 \\
\hline C35 & Fixed-free & & & 35.69 & 1000 & 900 & $8 \phi 16$ & 16.08 & 1.61 & $2(6 \phi 8)$ & 1.6225 \\
\hline C36 & Fixed-free & & & 35.69 & 1000 & 900 & $8 \phi 16$ & 16.08 & 1.61 & $2(10 \phi 8)$ & 2.7 \\
\hline C37 & Fixed-fixed & & & 27.65 & 600 & 300 & $4 \phi 18$ & $\begin{array}{ll}10.17 \\
\end{array}$ & 1.7 & $6 \phi 8$ & 0.6 \\
\hline C38 & Hinged-hinged & & & 27.65 & 600 & 300 & $4 \phi 18$ & 10.17 & 1.7 & $6 \phi 8$ & 0.6 \\
\hline C39 & Fixed-hinged & & & 27.65 & 600 & 300 & $4 \phi 18$ & 10.17 & 1.7 & $6 \phi 8$ & 0.6 \\
\hline C40 & Fixed-free & & & 27.65 & 600 & 300 & $4 \phi 18$ & 10.17 & 1.7 & $6 \phi 8$ & 0.6 \\
\hline C41 & Fixed-fixed & & & 27.65 & 600 & 600 & $4 \phi 18$ & 10.17 & 1.7 & $66 \phi 8$ & 0.6 \\
\hline C42 & Hinged-hinged & & & 27.65 & 600 & 600 & $4 \phi 18$ & 10.17 & 1.7 & $6 \phi 8$ & 0.6 \\
\hline C43 & Fixed-hinged & & & 27.65 & 600 & 600 & $4 \phi 18$ & 10.17 & 1.7 & $6 \phi 8$ & 0.6 \\
\hline C44 & Fixed-free & & & 27.65 & 600 & 600 & $4 \phi 18$ & 10.17 & 1.7 & $6 \phi 8$ & 0.6 \\
\hline C45 & Fixed-fixed & & & 27.65 & 600 & 900 & $4 \phi 18$ & $\begin{array}{l}10.17 \\
\end{array}$ & 1.7 & 668 & 0.6 \\
\hline C46 & Hinged-hinged & & & 27.65 & 600 & 900 & $4 \phi 18$ & 10.17 & 1.7 & $6 \phi 8$ & 0.6 \\
\hline C47 & Fixed-hinged & & & 27.65 & 600 & 900 & $4 \phi 18$ & 10.17 & 1.7 & $6 \phi 8$ & 0.6 \\
\hline C48 & Fixed-free & & & 27.65 & 600 & 900 & $4 \phi 18$ & 10.17 & 1.7 & $6 \phi 8$ & 0.6 \\
\hline
\end{tabular}


Table (3): Properties of Studied R.C Columns for Square Section.

\begin{tabular}{|c|c|c|c|c|c|c|c|c|c|c|c|}
\hline \multirow{2}{*}{$\begin{array}{c}\text { Column } \\
\text { No. } \\
\text { designation }\end{array}$} & \multirow[b]{2}{*}{ End condition } & \multirow{2}{*}{$\begin{array}{l}\text { Shape } \\
\text { of cross } \\
\text { section }\end{array}$} & \multirow{2}{*}{$\begin{array}{l}\text { Height } \\
\text { of } \\
\text { column } \\
\text { (L)cm }\end{array}$} & \multicolumn{2}{|c|}{$\begin{array}{l}\text { Cross-section } \\
\text { dimensions }\end{array}$} & \multirow{2}{*}{$\begin{array}{c}\text { Grade of } \\
\text { used } \\
\text { concrete } \\
f_{\mathrm{cu}} \\
\mathrm{kg} / \mathrm{cm}^{2}\end{array}$} & \multicolumn{3}{|c|}{ Longitudinal reinforcement } & \multicolumn{2}{|c|}{ Transverse reinforcement } \\
\hline & & & & $\begin{array}{l}(\mathrm{b} \times \mathrm{t}) \text { or } \mathrm{D} \\
(\mathrm{cm})\end{array}$ & $\mathrm{Ag}^{2}$ & & $\begin{array}{l}\text { No. of } \\
\text { bars }\end{array}$ & $\begin{array}{c}\text { Area of } \\
\text { Reinf. } \\
\mathrm{Cm}^{2} \\
\end{array}$ & $\begin{array}{c}\% \text { of } \\
\text { Reinf. }(\mu)\end{array}$ & $\begin{array}{l}\text { No. of Ties } \\
\text { and Diameter } \\
\text { of bars }(\mathrm{mm})\end{array}$ & $\begin{array}{c}\text { Volumetri } \\
\text { c ratio } \\
\text { ( } \rho s) \% \\
\end{array}$ \\
\hline C49 & Fixed-free & \multirow{24}{*}{ 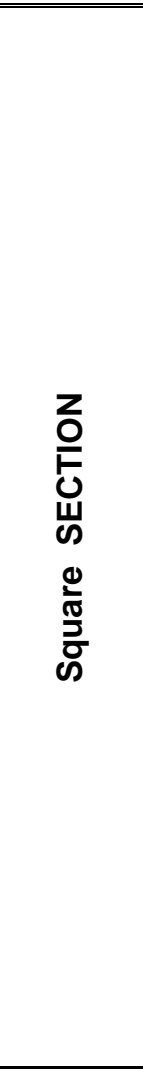 } & \multirow{24}{*}{$\begin{array}{l}\text { E் } \\
0 \\
8 \\
\text { ํ } \\
\text { II } \\
-\end{array}$} & $31.62 \times 31.62$ & 1000 & 300 & $4 \phi 16$ & 16.08 & 1.61 & 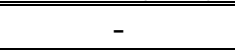 & 0 \\
\hline $\mathrm{C50}$ & Fixed-free & & & $31.62 \times 31.62$ & 1000 & 300 & $4 \phi 16$ & 16.08 & 1.61 & $6 \phi 8$ & 1.023 \\
\hline $\mathrm{C51}$ & Fixed-free & & & $31.62 \times 31.62$ & 1000 & 300 & $4 \phi 16$ & 16.08 & 1.61 & $2 \times 6 \phi 8$ & 1.6225 \\
\hline $\mathrm{C} 52$ & Fixed-free & & & $31.62 \times 31.62$ & 1000 & 300 & $4 \phi 16$ & 16.08 & 1.61 & $2 \times 10 \phi 8$ & 2.7 \\
\hline C53 & Fixed-free & & & $31.62 \times 31.62$ & 1000 & 600 & $4 \phi 16$ & 16.08 & 1.61 & - & 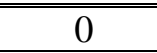 \\
\hline C54 & Fixed-free & & & $31.62 \times 31.62$ & 1000 & 600 & $4 \phi 16$ & 16.08 & 1.61 & $6 \phi 8$ & 1.023 \\
\hline C55 & Fixed-free & & & $31.62 \times 31.62$ & 1000 & 600 & $4 \phi 16$ & 16.08 & 1.61 & $2 \times 6 \phi 8$ & 1.6225 \\
\hline C56 & Fixed-free & & & $31.62 \times 31.62$ & 1000 & 600 & $4 \phi 16$ & 16.08 & 1.61 & $2 \times 10 \phi 8$ & 2.7 \\
\hline C57 & Fixed-free & & & $31.62 \times 31.62$ & 1000 & 900 & $8 \phi 16$ & 16.08 & 1.61 & - & 0 \\
\hline C58 & Fixed-free & & & $31.62 \times 31.62$ & 1000 & 900 & $8 \phi 16$ & 16.08 & 1.61 & $6 \phi 8$ & 1.023 \\
\hline C59 & Fixed-free & & & $31.62 \times 31.62$ & 1000 & 900 & $8 \phi 16$ & 16.08 & 1.61 & $2 \times 6 \phi 8$ & 1.6225 \\
\hline $\mathrm{C60}$ & Fixed-free & & & $31.62 \times 31.62$ & 1000 & 900 & $8 \phi 16$ & 16.08 & 1.61 & $2 \times 10 \phi 8$ & 2.7 \\
\hline C61 & Fixed-fixed & & & $24.5 \times 24.5$ & 600 & 300 & $4 \phi 18$ & 10.17 & 1.7 & $6 \phi 8$ & 0.6 \\
\hline C62 & Hinged-hinged & & & $24.5 \times 24.5$ & 600 & 300 & $4 \phi 18$ & 10.17 & 1.7 & $6 \phi 8$ & 0.6 \\
\hline C63 & Fixed-hinged & & & $24.5 \times 24.5$ & 600 & 300 & $4 \phi 18$ & 10.17 & 1.7 & $6 \phi 8$ & 0.6 \\
\hline $\mathrm{C} 64$ & Fixed-free & & & $24.5 \times 24.5$ & 600 & 300 & $4 \phi 18$ & 10.17 & 1.7 & $6 \phi 8$ & 0.6 \\
\hline C65 & Fixed-fixed & & & $24.5 \times 24.5$ & 600 & 600 & $4 \phi 18$ & 10.17 & 1.7 & $6 \phi 8$ & 0.6 \\
\hline $\mathrm{C} 66$ & Hinged-hinged & & & $24.5 \times 24.5$ & 600 & 600 & $4 \phi 18$ & 10.17 & 1.7 & $6 \phi 8$ & 0.6 \\
\hline C67 & Fixed-hinged & & & $24.5 \times 24.5$ & 600 & 600 & $4 \phi 18$ & 10.17 & 1.7 & $6 \phi 8$ & 0.6 \\
\hline C68 & Fixed-free & & & $24.5 \times 24.5$ & 600 & 600 & $4 \phi 18$ & 10.17 & 1.7 & $6 \phi 8$ & 0.6 \\
\hline C69 & Fixed-fixed & & & $24.5 \times 24.5$ & 600 & 900 & $4 \phi 18$ & 10.17 & 1.7 & $6 \phi 8$ & 0.6 \\
\hline $\mathrm{C} 70$ & Hinged-hinged & & & $24.5 \times 24.5$ & 600 & 900 & $4 \phi 18$ & 10.17 & 1.7 & $6 \phi 8$ & 0.6 \\
\hline $\mathrm{C} 71$ & Fixed-hinged & & & $24.5 \times 24.5$ & 600 & 900 & $4 \phi 18$ & 10.17 & 1.7 & $6 \phi 8$ & 0.6 \\
\hline $\mathrm{C} 72$ & Fixed-free & & & $24.5 \times 24.5$ & 600 & 900 & $4 \phi 18$ & 10.17 & 1.7 & $6 \phi 8$ & 0.6 \\
\hline
\end{tabular}



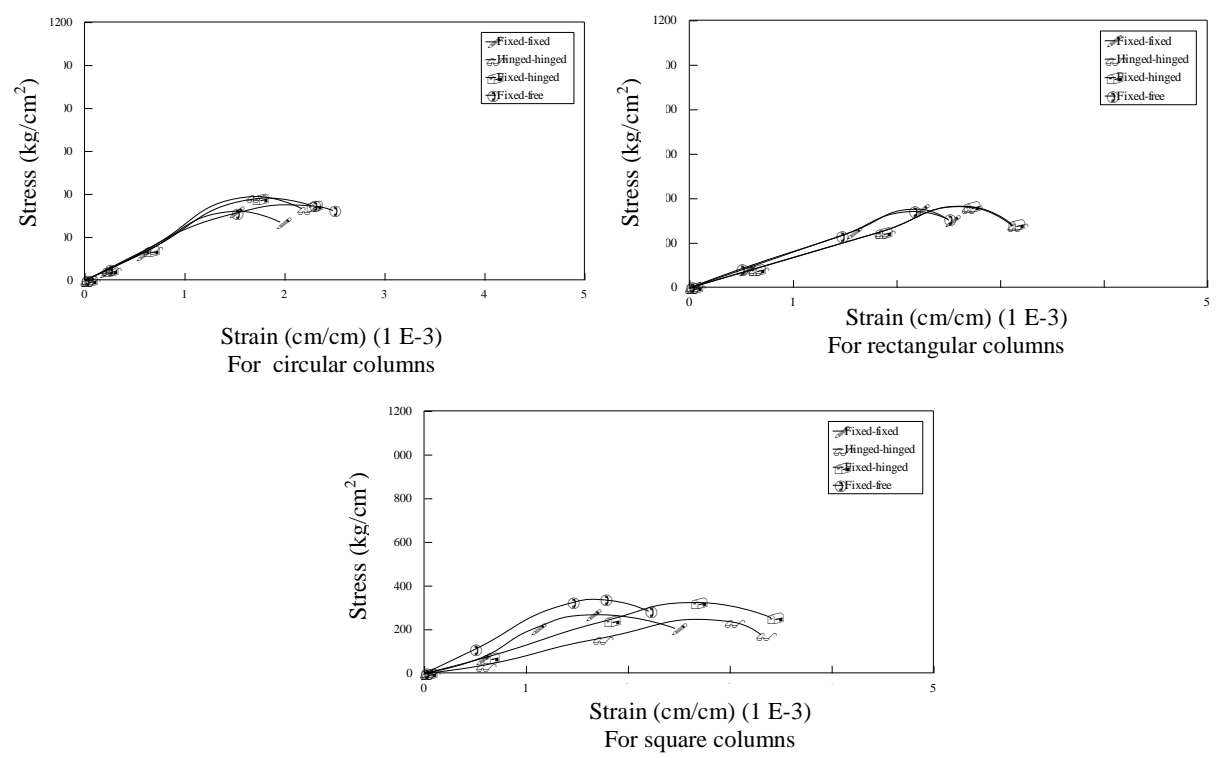

Fig. 3: Axial (stress-strain) diagram at different end condition (fixed-fixed, hingedhinged, fixed-hinged, fixed-free) for different shapes

(circular-rectangular -square) at grade of concrete

$$
f_{\mathrm{cu}}=300 \mathrm{~kg} / \mathrm{cm}^{2} \text { and } \rho_{\mathrm{s}}=0.6 \% \text {. }
$$
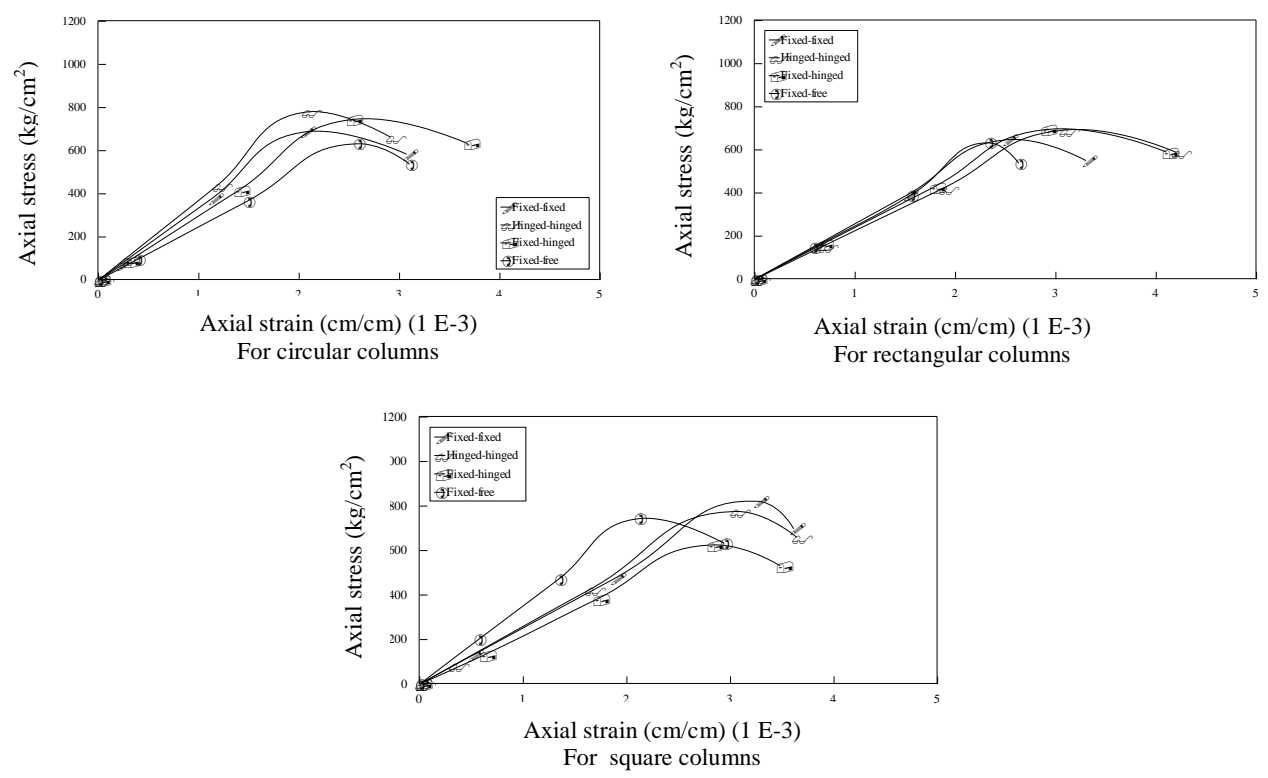

Fig. 4: Axial (stress-strain) diagram at different end condition (fixed-fixed, hingedhinged, fixed-hinged, fixed-free) for different shapes

(circular-rectangular-square) at grade of concrete

$$
\mathrm{f}_{\mathrm{cu}}=600 \mathrm{~kg} / \mathrm{cm}^{2} \text { and } \rho \mathrm{s}=0.6 \% \text {. }
$$



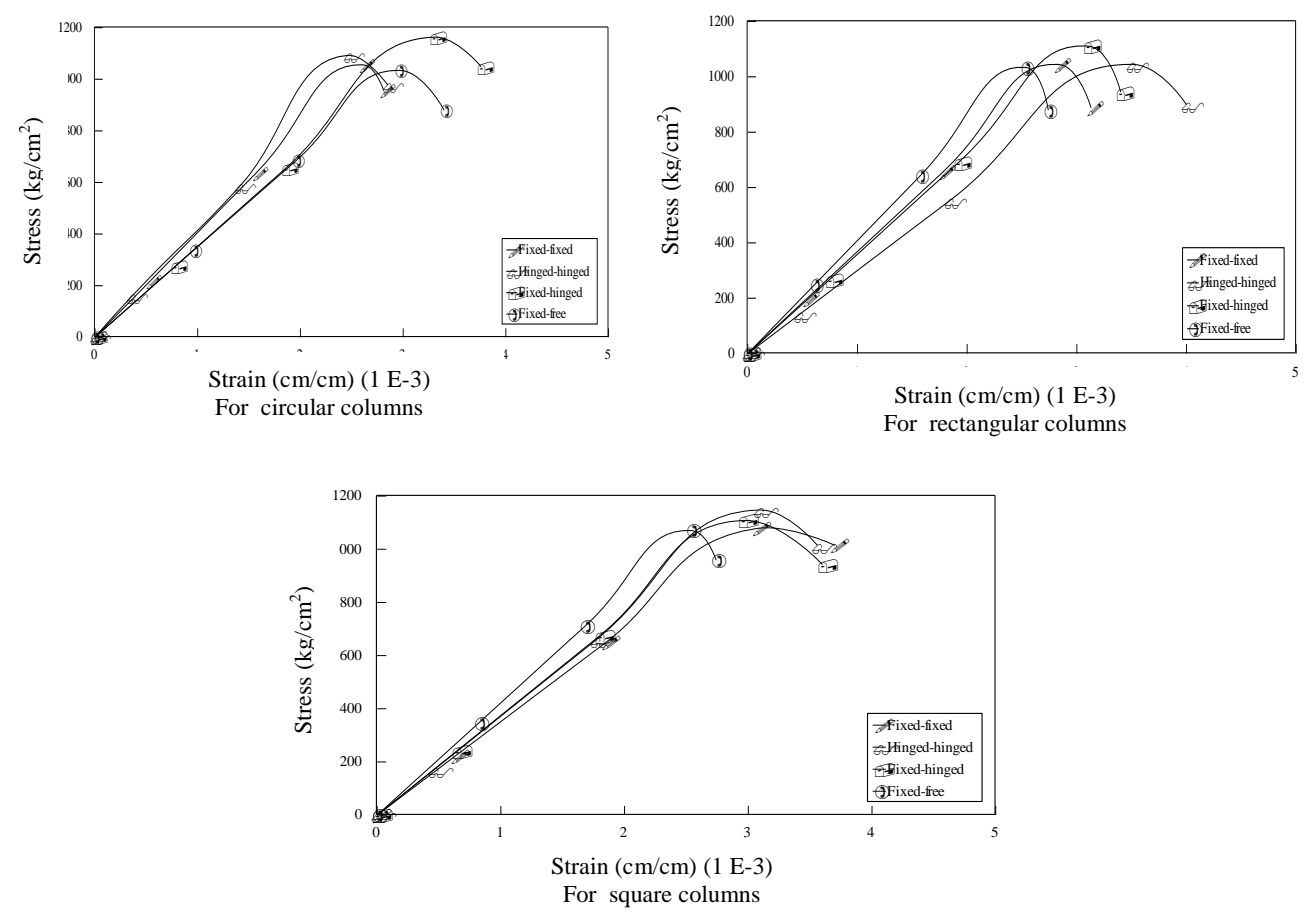

Fig.5: Axial (stress-strain) diagram at different end condition (fixed-fixed, hingedhinged, fixed-hinged, fixed-free) for different shapes (circular-rectangular-square) at grade of concrete

$$
f_{\mathrm{cu}}=900 \mathrm{~kg} / \mathrm{cm}^{2} \text { and } \rho_{\mathrm{s}}=0.6 \% \text {. }
$$

\section{Lateral stress $\left(f_{\mathrm{cl}}\right)$-axial strain $\left(\varepsilon_{\mathrm{cc}}\right)$ relationship:}

Figures (6) (7) and (8) show samples of the obtained lateral stress $\left(f_{\mathrm{cl}}\right)$-axial strain $\left(\varepsilon_{\mathrm{cc}}\right)$ relationships for circular, rectangular and square sections with constant volumetric ratio $\left(\rho_{\mathrm{s}}=0.6 \%\right)$ using different grades of concrete $\left(f_{\mathrm{cu}}=300,600,900\right.$ $\mathrm{kg} / \mathrm{cm}^{2}$ ) for the different end condition of columns (fixed-fixed, hinged-hinged, fixedhinged and fixed-free).
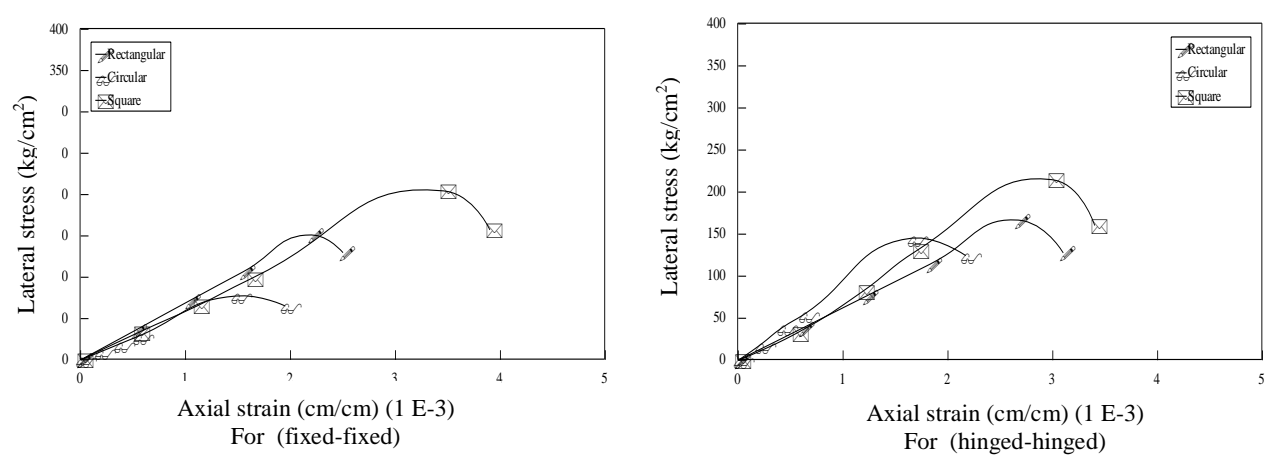

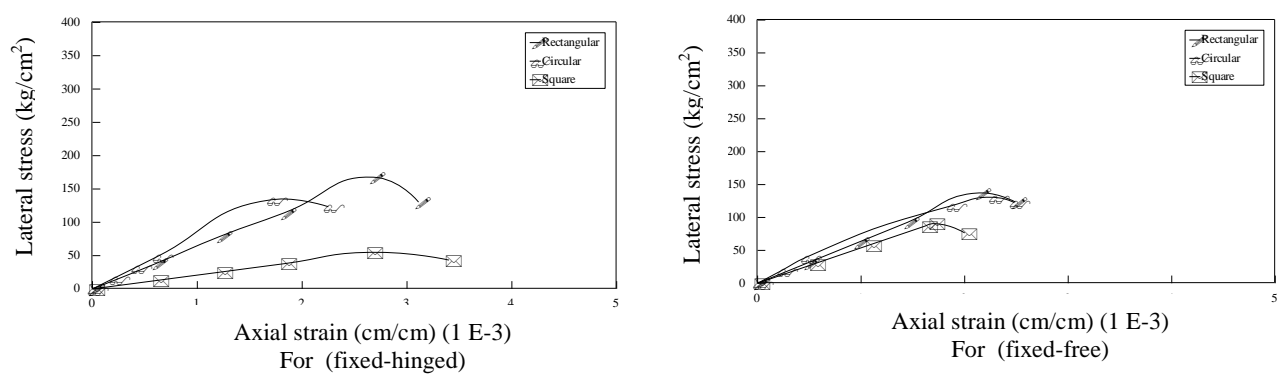

Fig. 6: (Lateral stress-axial strain)) diagram at different end condition (fixed-fixed, hinged-hinged, fixed-hinged, fixed-free) for different shapes (circular-rectangular-square) at grade of concrete $f_{\text {cu }}=300 \mathrm{~kg} / \mathrm{cm}^{2}$ and $\rho_{\mathrm{s}}=0.6 \%$.
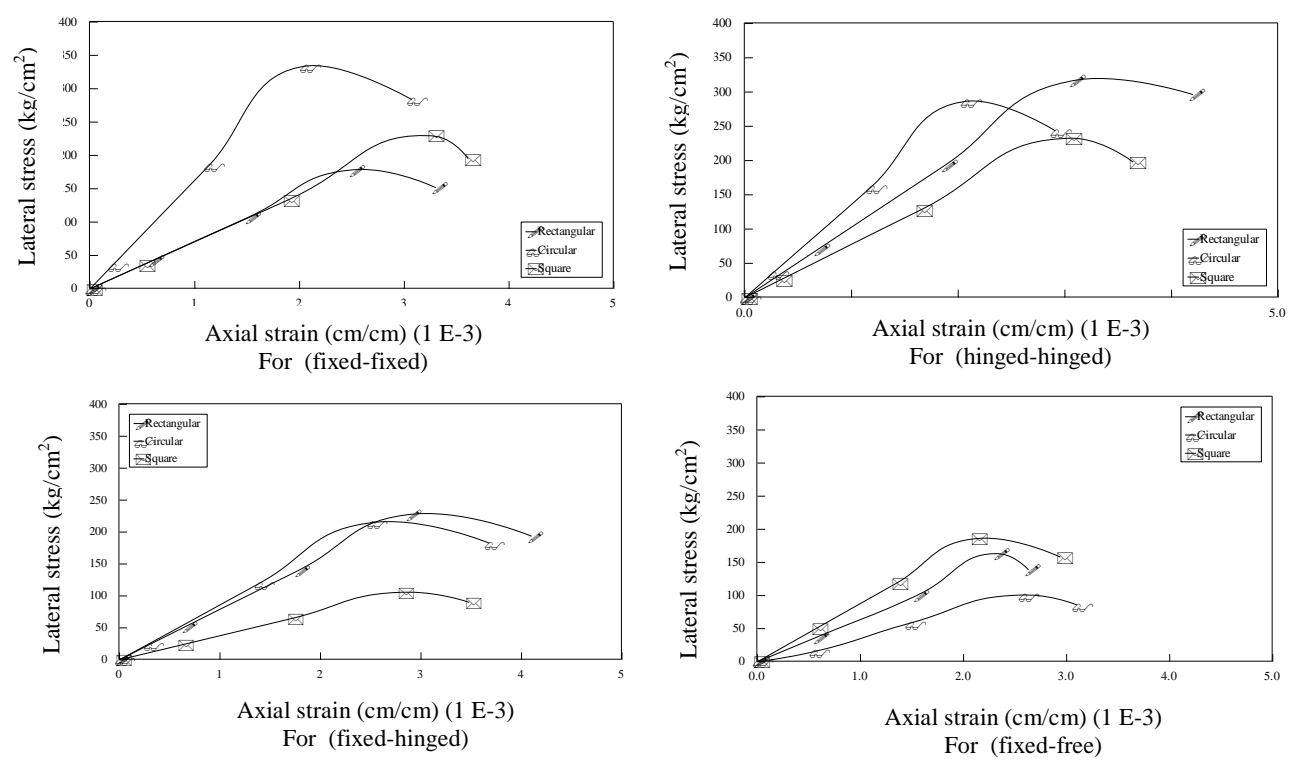

Fig. 7: (Lateral stress-axial strain)) diagram at different end condition (fixed-fixed, hinged-hinged, fixed-hinged, fixed-free) for different shapes

(circular-rectangular-square) at grade of concrete $f_{\mathrm{cu}}=600 \mathrm{~kg} / \mathrm{cm}^{2}$ and $\rho_{\mathrm{s}}=0.6 \%$.
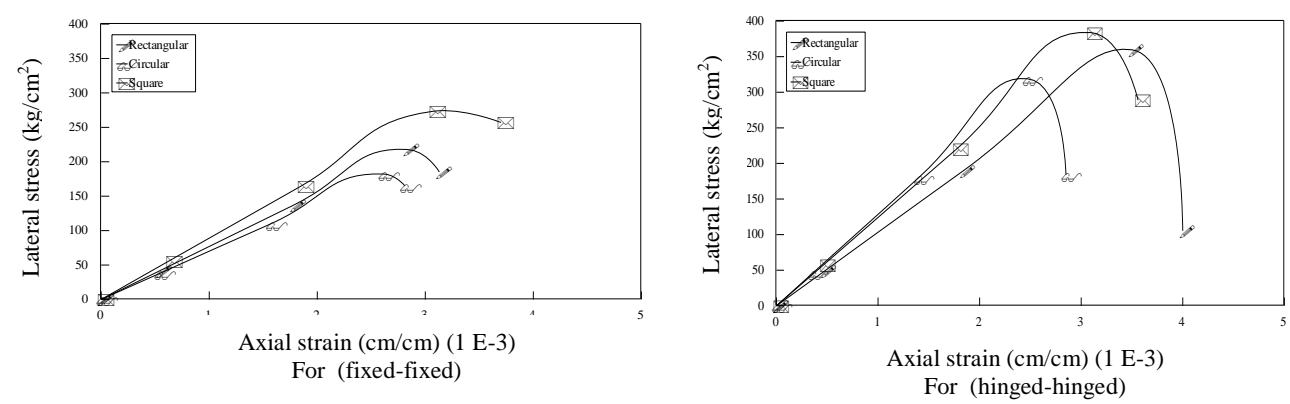

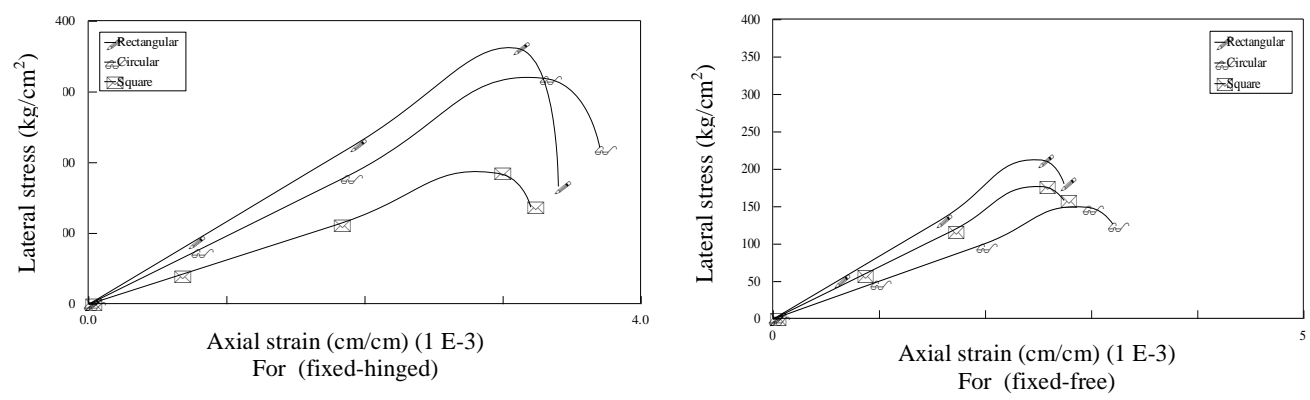

Fig. 8: (Lateral stress-axial strain)) diagram at different end condition (fixed-fixed, hinged-hinged, fixed-hinged, fixed-free) for different shapes

(circular-rectangular-square) at grade of concrete

$$
f_{\text {cu }}=900 \mathrm{~kg} / \mathrm{cm}^{2} \text { and } \rho_{\mathrm{s}}=0.6 \% \text {. }
$$

\section{Axial stress $\left(f_{\mathrm{cc}}\right)$-lateral strain $\left(\varepsilon_{\mathrm{cl}}\right)$ relationship:}

Figures (9), (10) and (11) show samples of the obtained axial stress $\left(f_{\text {cc }}\right)$-lateral strain $\left(\varepsilon_{\mathrm{cl}}\right)$, relationships for circular, rectangular and square sections with constant volumetric ratio $\left(\rho_{\mathrm{s}}=0.6 \%\right)$ using different grades of concrete $\left(f_{\mathrm{cu}}=300,600,900\right.$ $\mathrm{kg} / \mathrm{cm}^{2}$ ) for the different end condition of columns (fixed-fixed, hinged-hinged, fixed-hinged and fixed-free).
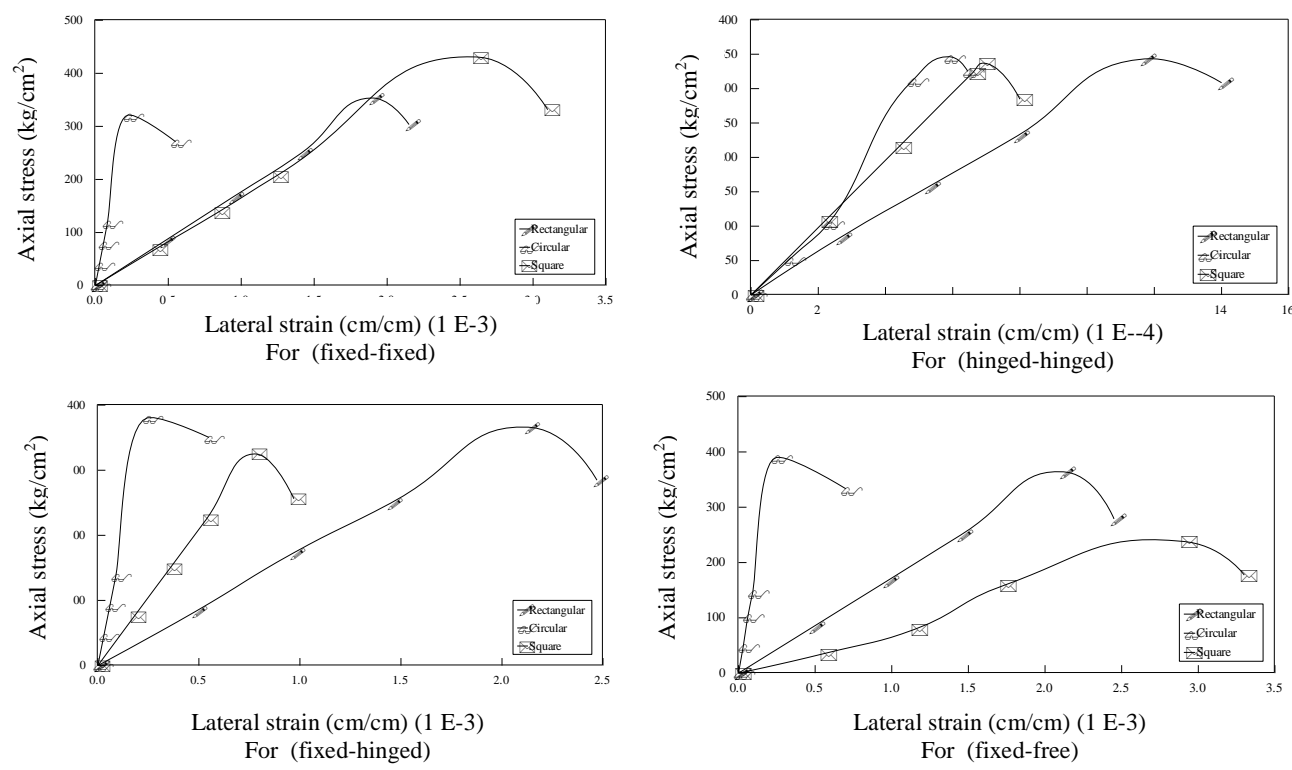

Fig.9: (Axial stress-lateral strain) diagram at different end condition (fixed-fixed, hinged-hinged, fixed-hinged, fixed-free) for different shapes

(circular-rectangular-square) at grade of concrete

$$
f_{\mathrm{cu}}=300 \mathrm{~kg} / \mathrm{cm}^{2} \text { and } \rho_{\mathrm{s}}=0.6 \% \text {. }
$$



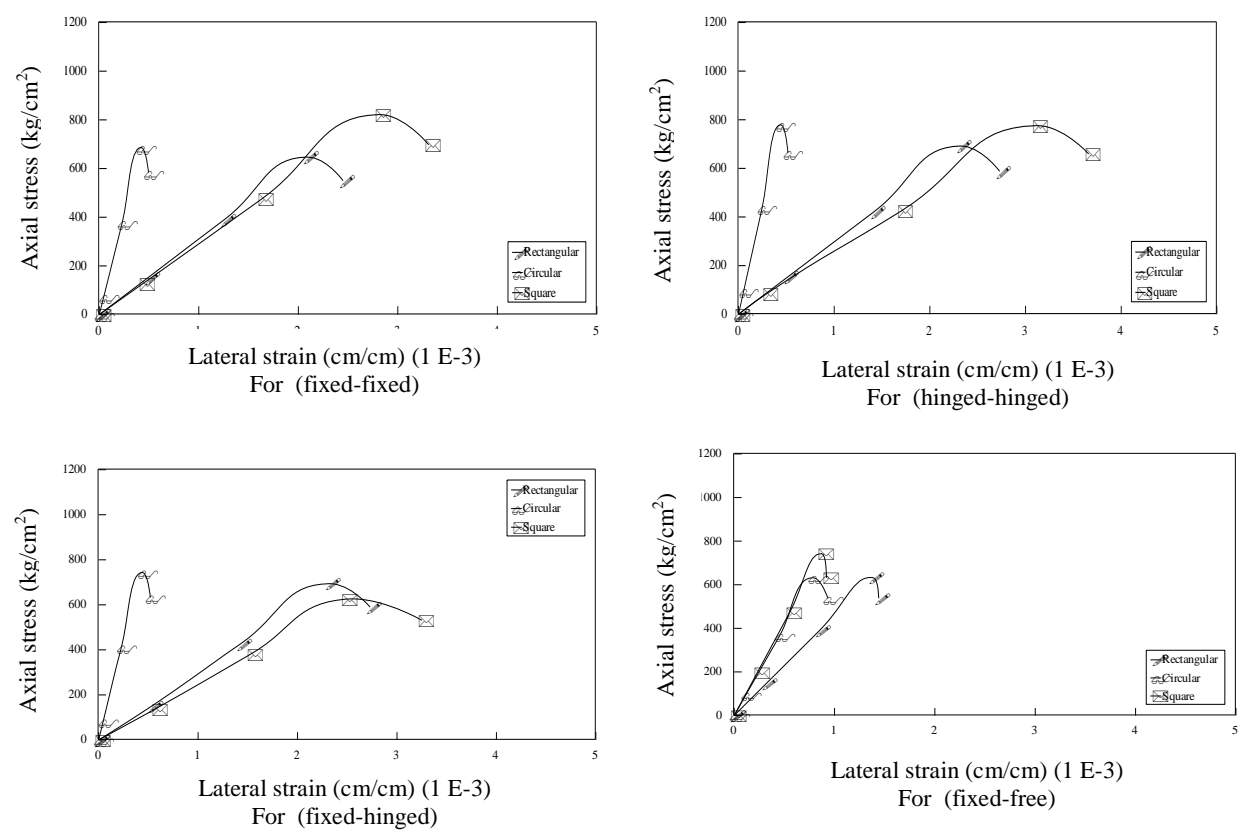

Fig.10: (Axial stress-lateral strain) diagram at different end condition (fixed-fixed, hinged-hinged, fixed-hinged, fixed-free) for different shapes (circular-rectangular-square) at grade of concrete $f_{\mathrm{cu}}=600 \mathrm{~kg} / \mathrm{cm}^{2}$ and $\rho_{\mathrm{s}}=0.6 \%$.
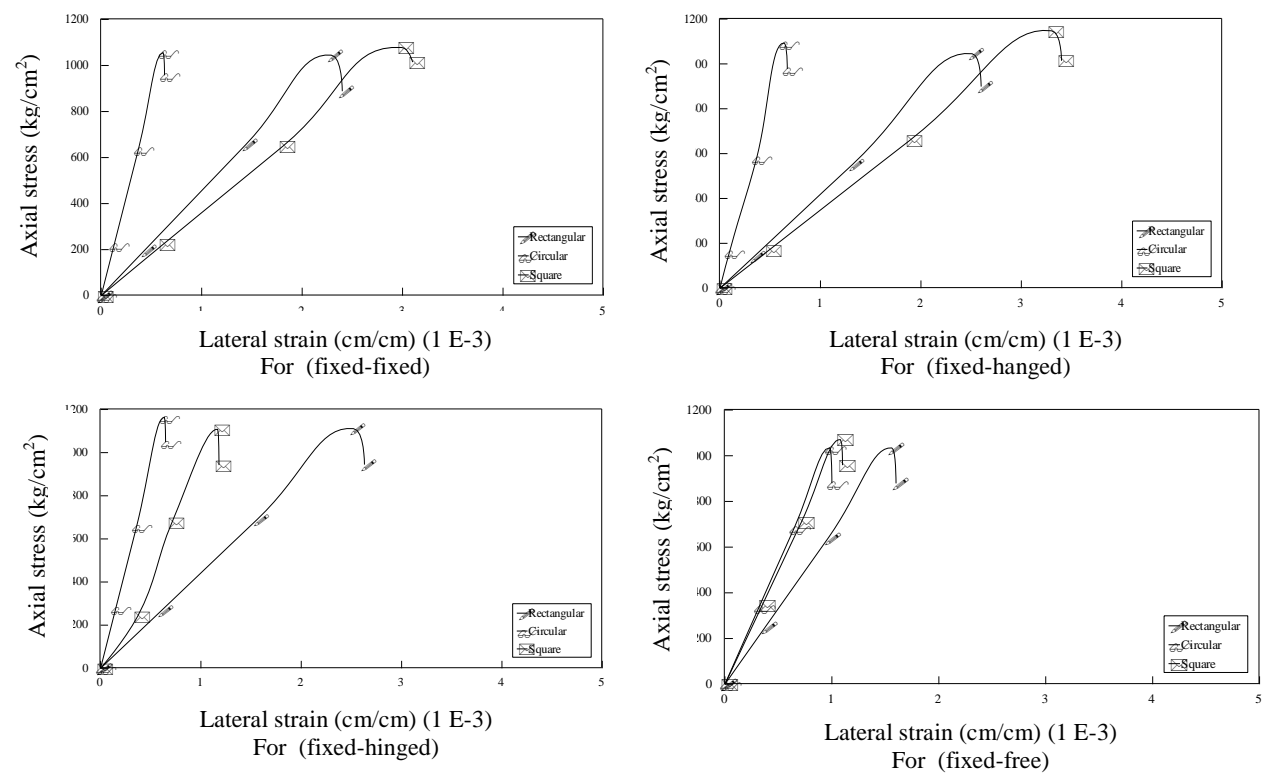

Fig. 11: (Axial stress-lateral strain) diagram at different end condition (fixed-fixed, hinged-hinged, fixed-hinged, fixed-free) for different shapes (circular-rectangularsquare) at grade of concrete $f_{\text {cu }}=900 \mathrm{~kg} / \mathrm{cm}^{2}$ and $\rho_{\mathrm{s}}=0.6 \%$. 


\section{Axial stress $\left(f_{\mathrm{cc}}\right)$-lateral stress $\left(f_{\mathrm{cl}}\right)$ relationship:}

Figures (12), (13) and (14) show samples of the obtained axial stress $\left(f_{\mathrm{cc}}\right)$-lateral stress $\left(f_{\mathrm{cl}}\right)$ relationships for circular, rectangular and square section with constant volumetric ratio $\left(\rho_{\mathrm{s}}=0.6 \%\right)$ using different grades of concrete $\left(f_{\text {cu }}=300,600,900\right.$ $\mathrm{kg} / \mathrm{cm}^{2}$ ) for the different end condition of columns (fixed-fixed, hinged-hinged, fixed-hinged and fixed-free).
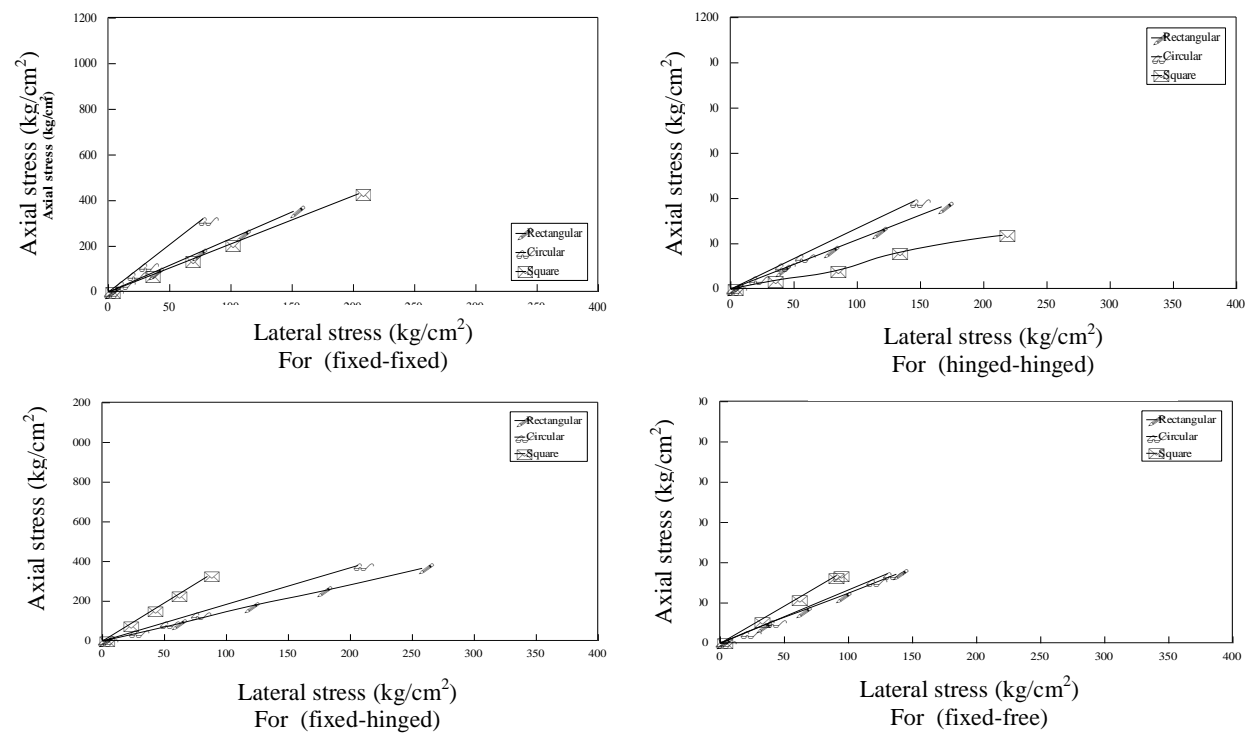

Fig.12: (Axial stress-lateral stress) diagram at different end condition (fixed-fixed, hingedhinged, fixed-hinged, fixed-free) for different shapes (circular-rectangular-square) at grade of concrete $f_{\mathrm{cu}}=300 \mathrm{~kg} / \mathrm{cm}^{2}$ and $\rho_{\mathrm{s}}=0.6 \%$.
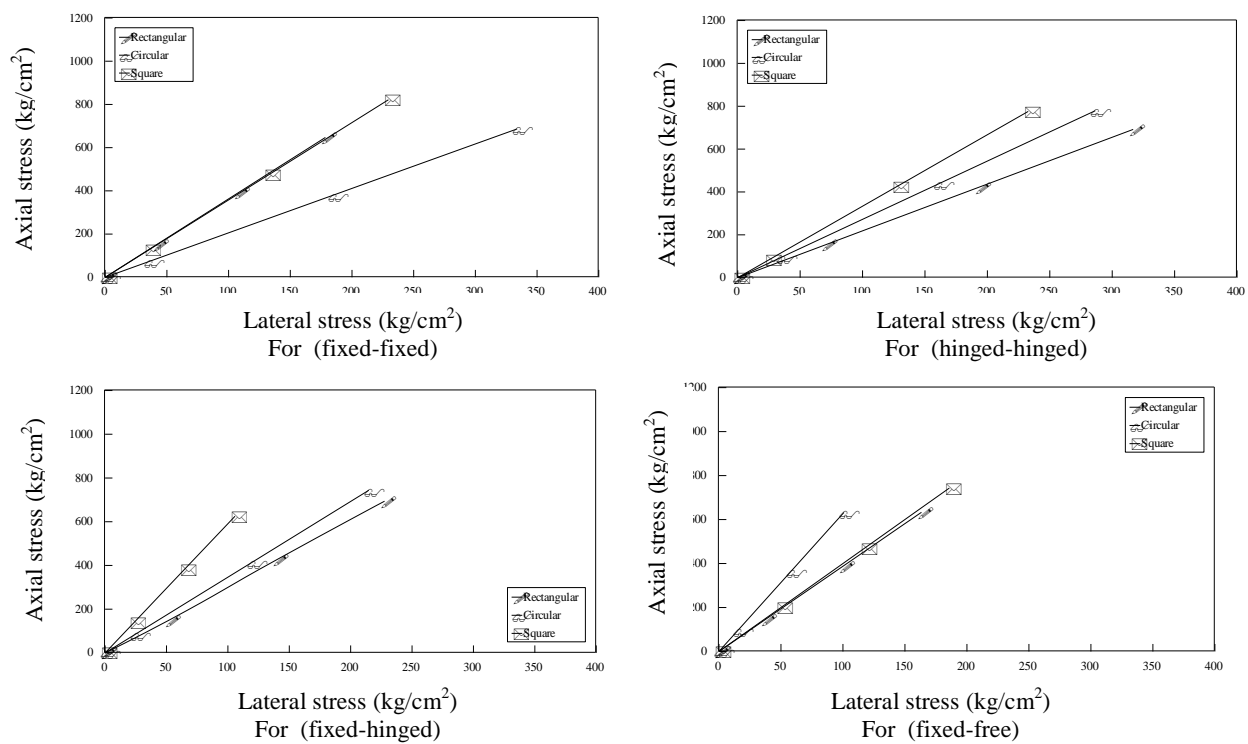

Fig.13: (Axial stress-lateral stress) diagram at different end condition (fixed-fixed, hingedhinged, fixed-hinged, fixed-free) for different shapes (circular-rectangular-square) at grade of concrete $f_{\text {cu }}=600 \mathrm{~kg} / \mathrm{cm}^{2}$ and $\rho_{\mathrm{s}}=0.6 \%$. 

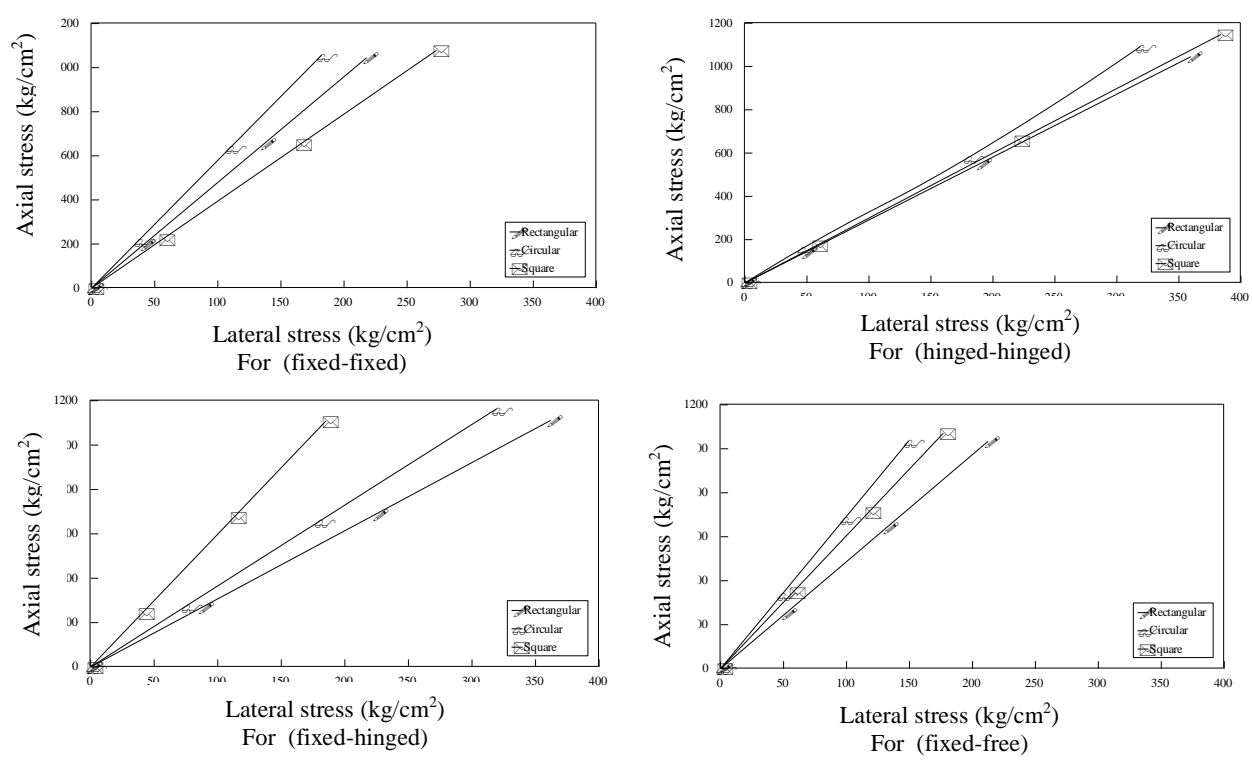

Fig.14: (Axial stress-lateral stress) diagram at different end condition (fixed-fixed, hinged-hinged, fixed-hinged, fixed-free) for different shapes (circular-rectangularsquare) at grade of concrete $f_{\text {cu }}=900 \mathrm{~kg} / \mathrm{cm}^{2}$ and $\rho_{\mathrm{s}}=0.6 \%$.

\section{DISCUSSION OF THE THEORETICAL RESULTS}

Here this research is only focusing on the effect of following parameters upon the theoretical static behavior of axial short columns in terms of the induced stresses and strains of such as columns:

1. Volumetric ratio of stirrups.

2. End condition.

3. Shape of cross-section; either of circular, rectangular or square.

4. Grade of concrete.

Tables (4), (5) and (6) summarizes the obtained theoretical both maximum stresses and strains for the studied columns. To declare how the included parameters influence the various calculated values represented by the maximum induced axial stresses and strains it is beneficial to be taken as ratios based on the reference grades of concrete. The effect of the third and fourth parameters is interrelated with both first and second parameters as follows:

\section{1- Effect of Volumetric Ratio on Maximum Stresses and Strains}

Figures (15), (16) and (17) shows how the ratios of $\left(f_{\mathrm{cc}} / f_{\mathrm{cu}}\right),\left(f_{\mathrm{cl}} / f_{\mathrm{cc}}\right),\left(f_{\mathrm{cl}} / f_{\mathrm{cu}}\right)$ and $\left(\varepsilon_{\mathrm{cl}} / \varepsilon_{\mathrm{cc}}\right)$ are affected by the above mentioned parameters, volumetric ratio $\left(\rho_{\mathrm{s}} \%\right)$, grade of concrete and shape of cross-sections for constant end condition. Examination of all figures shows that:

- For a constant grade of concrete and constant end condition the induced maximum axial stresses $\left(f_{\mathrm{cc}}\right)$ increases with increases of $\left(\rho_{\mathrm{s}} \%\right)$. 
- The effect of volumetric ratio $\left(\rho_{\mathrm{s}} \%\right)$ with the induced maximum axial stress $\left(f_{\text {cc }}\right)$ for section of constant end conditions (fixed-free) for different shapes of cross-sections for different used grades of concrete $\left(300,600,900 \mathrm{~kg} / \mathrm{cm}^{2}\right)$ reflects that the induced maximum axial stress $\left(f_{\mathrm{cc}}\right)$ with the increase of the volumetric ratio $\left(\rho_{\mathrm{s}} \%\right)$ and the rate of increase depend on both grade of concrete and shape of cross-sections.

- The effect of volumetric ratio $\left(\rho_{\mathrm{s}} \%\right)$ up on the induced lateral stress $\left(f_{\mathrm{cl}}\right)$ for sections having different shapes of cross-sections for constant end condition (fixed-free) reflects the fact that these induced lateral stress also are affected by the all volumetric ratio $\left(\rho_{\mathrm{s}} \%\right)$ concrete grade and shape of cross-section.

- Also, it is shown how the ratios of $\left(f_{\mathrm{cc}} / f_{\mathrm{cu}}\right),\left(f_{\mathrm{cl}} / f_{\mathrm{cc}}\right),\left(f_{\mathrm{cl}} / f_{\mathrm{cu}}\right)$ and $\left(\varepsilon_{\mathrm{cl}} / \varepsilon_{\mathrm{cc}}\right)$ are affected by the above mentioned parameters, volumetric ratio $\left(\rho_{\mathrm{s}} \%\right)$, grade of concrete and shape of cross-sections for constant end condition.
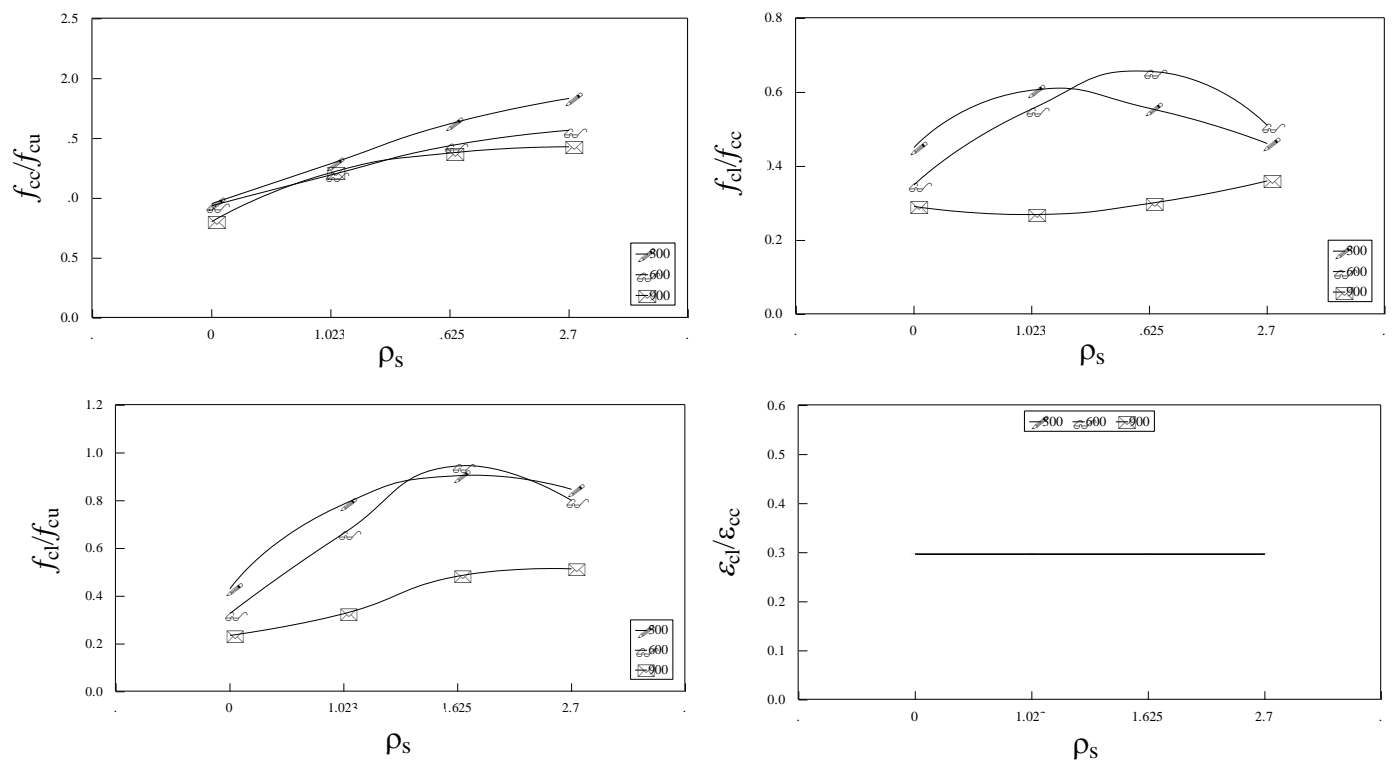

Fig.15: Effect of volumetric ratio $\left(\rho_{\mathrm{s}} \%\right)$ on the ratios of the induced maximum stress and strains for axial R.C columns for different shapes of cross-section with constant end condition (fixed-free) for circular columns 
Table (4): The Obtained Theoretical Maximum Stresses and Maximum Strains for Studied Columns For Rectangular Sections.

\begin{tabular}{|c|c|c|c|c|c|c|c|c|c|c|}
\hline $\begin{array}{l}\text { Column No. } \\
\text { designation }\end{array}$ & End condition & $\begin{array}{l}\text { Shape of } \\
\text { cross } \\
\text { section }\end{array}$ & $\begin{array}{l}\text { Grade of } \\
\text { concrete } f_{\text {cu }} \\
\mathrm{kg} / \mathrm{cm}^{2}\end{array}$ & $\begin{array}{l}\text { Percent } \\
\text { Reinf. } \\
\mu_{\mathrm{s}}(\%)\end{array}$ & $\begin{array}{c}\text { Volumetri } \\
\text { c ratio } \\
\rho_{\mathrm{s}}(\%)\end{array}$ & $f_{\mathrm{cc}}\left(\mathrm{kg} / \mathrm{cm}^{2}\right)$ & $f_{\mathrm{cl}}\left(\mathrm{kg} / \mathrm{cm}^{2}\right)$ & $\begin{array}{l}\varepsilon_{\mathrm{cc}} \times 10^{-5} \\
(\mathrm{~cm} / \mathrm{cm})\end{array}$ & $\begin{array}{l}\varepsilon_{\mathrm{cl}} \times 10^{-5} \\
(\mathrm{~cm} / \mathrm{cm})\end{array}$ & $\begin{array}{l}\varepsilon_{\mathrm{cf}} \mathrm{x} 10^{-5} \\
(\mathrm{~cm} / \mathrm{cm})\end{array}$ \\
\hline C1 & Fixed-free & \multirow{24}{*}{ 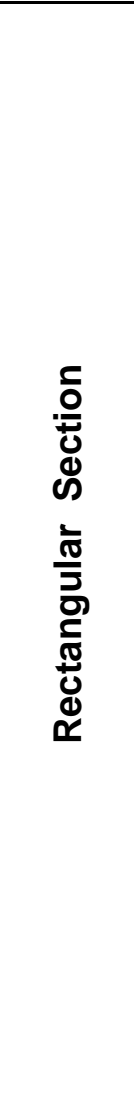 } & 300 & 1.61 & 0 & 242.5 & 69.16 & 31.0 & 9.39 & 41.0 \\
\hline $\mathrm{C} 2$ & Fixed-free & & 300 & 1.61 & 1.023 & 344.78 & 104.77 & 52.8 & 15.70 & 163.0 \\
\hline C3 & Fixed-free & & 300 & 1.61 & 1.6225 & 413.61 & 201.35 & 69.0 & 20.5 & 213.0 \\
\hline $\mathrm{C} 4$ & Fixed-free & & 300 & 1.61 & 2.70 & 462.27 & 299.19 & 72.6 & 21.6 & 310.0 \\
\hline $\mathrm{C} 5$ & Fixed-free & & 600 & 1.61 & 0 & 547.12 & 158.20 & 106.0 & 31.5 & 122.0 \\
\hline C6 & Fixed-free & & 600 & 1.61 & 1.023 & 704.62 & 287.94 & 131.0 & 39.0 & 221.0 \\
\hline $\mathrm{C7}$ & Fixed-free & & 600 & 1.61 & 1.6225 & 831.44 & 405.08 & 163.0 & 48.4 & 261.0 \\
\hline $\mathrm{C} 8$ & Fixed-free & & 600 & 1.61 & 2.70 & 871.74 & 565.43 & 188.0 & 55.8 & 262.0 \\
\hline C9 & Fixed-free & & 900 & 1.61 & 0 & 706.44 & 201.89 & 154.0 & 45.7 & 164.0 \\
\hline $\mathrm{C} 10$ & Fixed-free & & 900 & 1.61 & 1.023 & 967.92 & 277.17 & 158.0 & 46.9 & 200.0 \\
\hline $\mathrm{C} 11$ & Fixed-free & & 900 & 1.61 & 1.6225 & 1157.22 & 378.48 & 252.0 & 74.3 & 312.0 \\
\hline $\mathrm{C} 12$ & Fixed-free & & 900 & 1.61 & 2.70 & 1219.59 & 570.126 & 265.0 & 78.0 & 320.0 \\
\hline $\mathrm{C} 13$ & Fixed-fixed & & 300 & 1.70 & 0.6 & 353.55 & 151.17 & 220.0 & 190.0 & 250.0 \\
\hline $\mathrm{C} 14$ & Hinged-hinged & & 300 & 1.70 & 0.6 & 364.00 & 166.72 & 267.0 & 211.7 & 310.0 \\
\hline $\mathrm{C} 15$ & Fixed-hinged & & 300 & 1.70 & 0.6 & 366.14 & 167.68 & 268.0 & 213.0 & 311.0 \\
\hline $\mathrm{C} 16$ & Fixed-free & & 300 & 1.70 & 0.6 & 343.20 & 137.34 & 216.0 & 117.0 & 240.0 \\
\hline $\mathrm{C} 17$ & Fixed-fixed & & 600 & 1.70 & 0.6 & 647.28 & 178.44 & 251.0 & 209.0 & 330.0 \\
\hline $\mathrm{C} 18$ & Hinged-hinged & & 600 & 1.70 & 0.6 & 691.97 & 316.79 & 308.0 & 232.0 & 420.0 \\
\hline C19 & Fixed-hinged & & 600 & 1.70 & 0.6 & 694.02 & 227.6 & 289.0 & 232.0 & 410.0 \\
\hline $\mathrm{C} 20$ & Fixed-free & & 600 & 1.70 & 0.6 & 633.03 & 163.33 & 233.0 & 138.0 & 263.0 \\
\hline $\mathrm{C} 21$ & Fixed-fixed & & 900 & 1.70 & 0.6 & 1044.96 & 217.98 & 283.0 & 229.0 & 313.0 \\
\hline $\mathrm{C} 22$ & Hinged-hinged & & 900 & 1.70 & 0.6 & 1045.27 & 251.76 & 350.0 & 251.0 & 400.0 \\
\hline $\mathrm{C} 23$ & Fixed-hinged & & 900 & 1.70 & 0.6 & 1111.33 & 253.48 & 310.0 & 252.0 & 340.0 \\
\hline $\mathrm{C} 24$ & Fixed-free & & 900 & 1.70 & 0.6 & 1034.18 & 212.47 & 253.0 & 156.0 & 274.0 \\
\hline
\end{tabular}


Table (5): The Obtained Theoretical Maximum Stresses and Maximum Strains for Studied Columns For Circular Sections.

\begin{tabular}{|c|c|c|c|c|c|c|c|c|c|c|}
\hline $\begin{array}{l}\text { Column No. } \\
\text { designation }\end{array}$ & End condition & $\begin{array}{l}\text { Shape of } \\
\text { cross } \\
\text { section }\end{array}$ & $\begin{array}{l}\text { Grade of } \\
\text { concrete } f_{\mathrm{cu}} \\
\mathrm{kg} / \mathrm{cm}^{2}\end{array}$ & $\begin{array}{l}\text { Percent } \\
\text { Reinf. } \\
\mu_{s}(\%)\end{array}$ & $\begin{array}{l}\text { Volumetri } \\
\text { c ratio } \\
\rho_{\mathrm{s}}(\%)\end{array}$ & $f_{\mathrm{cc}}\left(\mathrm{kg} / \mathrm{cm}^{2}\right)$ & $f_{\mathrm{cl}}\left(\mathrm{kg} / \mathrm{cm}^{2}\right)$ & $\begin{array}{c}\varepsilon_{\mathrm{cc}} \times 10^{-5} \\
(\mathrm{~cm} / \mathrm{cm})\end{array}$ & $\begin{array}{l}\varepsilon_{\mathrm{cl}} \times 10^{-5} \\
(\mathrm{~cm} / \mathrm{cm})\end{array}$ & $\begin{array}{l}\varepsilon_{\mathrm{c} \times \mathrm{X} 10^{-5}} \\
(\mathrm{~cm} / \mathrm{cm})\end{array}$ \\
\hline $\mathrm{C} 25$ & Fixed-free & \multirow{24}{*}{$\begin{array}{l}\frac{0}{0} \\
\frac{0}{0} \\
\text { ஸ } \\
\frac{1}{5} \\
\frac{0}{0} \\
\frac{1}{0}\end{array}$} & 300 & 1.61 & 0 & 287.0 & 129.31 & 21.3 & 6.33 & 31.2 \\
\hline $\mathrm{C} 26$ & Fixed-free & & 300 & 1.61 & 1.023 & 359.31 & 235.81 & 98.0 & 9.33 & 175.0 \\
\hline $\mathrm{C} 27$ & Fixed-free & & 300 & 1.61 & 1.6225 & 486.95 & 271.41 & 64.4 & 13.8 & 127.0 \\
\hline $\mathrm{C} 28$ & Fixed-free & & 300 & 1.61 & 2.70 & 550.406 & 254.31 & 52.0 & 15.5 & 236.0 \\
\hline $\mathrm{C} 29$ & Fixed-free & & 600 & 1.61 & 0 & 563.47 & 256.16 & 80.6 & 18.5 & 92.7 \\
\hline $\mathrm{C} 30$ & Fixed-free & & 600 & 1.61 & 1.023 & 717.5 & 398.41 & 70.1 & 20.8 & 220.0 \\
\hline C31 & Fixed-free & & 600 & 1.61 & 1.6225 & 864.6 & 567.76 & 97.0 & 28.8 & 176.0 \\
\hline $\mathrm{C} 32$ & Fixed-free & & 600 & 1.61 & 2.70 & 940.8 & 480.53 & 116.0 & 34.4 & 211.0 \\
\hline $\mathrm{C} 33$ & Fixed-free & & 900 & 1.61 & 0 & 724.8 & 212.36 & 89.0 & 26.4 & 110.0 \\
\hline C34 & Fixed-free & & 900 & 1.61 & 1.023 & 1093.36 & 294.14 & 102.0 & 30.3 & 161.0 \\
\hline $\mathrm{C} 35$ & Fixed-free & & 900 & 1.61 & 1.6225 & 1240.95 & 436.0 & 152.0 & 45.0 & 199.0 \\
\hline $\mathrm{C} 36$ & Fixed-free & & 900 & 1.61 & 2.70 & 1287.31 & 463.33 & 162.0 & 48.1 & 212.0 \\
\hline C37 & Fixed-free & & 300 & 1.70 & 0.6 & 321.56 & 77.31 & 148.0 & 22.6 & 195.0 \\
\hline C38 & Hinged-hinged & & 300 & 1.70 & 0.6 & 390.0 & 145.34 & 166.0 & 24.7 & 217.0 \\
\hline C39 & Fixed-hinged & & 300 & 1.70 & 0.6 & 380.55 & 133.98 & 171.0 & 24.7 & 225.0 \\
\hline $\mathrm{C} 40$ & Fixed-free & & 300 & 1.70 & 0.6 & 346.45 & $130 ., 65$ & 228.0 & 59.0 & 248.0 \\
\hline $\mathrm{C} 41$ & Fixed-free & & 600 & 1.70 & 0.6 & 686.7 & 333.86 & 205.0 & 42.1 & 307.0 \\
\hline $\mathrm{C} 42$ & Hinged-hinged & & 600 & 1.70 & 0.6 & 779.42 & 286.44 & 207.0 & 44.2 & 291.0 \\
\hline $\mathrm{C} 43$ & Fixed-hinged & & 600 & 1.70 & 0.6 & 743.94 & 214.77 & 251.0 & 44.1 & 368.0 \\
\hline $\mathrm{C} 44$ & Fixed-free & & 600 & 1.70 & 0.6 & 632.28 & 100.85 & 258.0 & 78.5 & 310.0 \\
\hline $\mathrm{C} 45$ & Fixed-free & & 900 & 1.70 & 0.6 & 1056.3 & 182.27 & 261.0 & 61.6 & 281.0 \\
\hline $\mathrm{C} 46$ & Hinged-hinged & & 900 & 1.70 & 0.6 & 1092.91 & 223,125 & 247.0 & 63.7 & 285.0 \\
\hline $\mathrm{C} 47$ & Fixed-hinged & & 900 & 1.70 & 0.6 & 1163.48 & 222.87 & 330.0 & 63.6 & 370.0 \\
\hline $\mathrm{C} 48$ & Fixed-free & & 900 & 1.70 & 0.6 & 1034.65 & 149.33 & 296.0 & 98.0 & 320.0 \\
\hline
\end{tabular}


Table (6): The Obtained Theoretical Maximum Stresses and Maximum Strains for Studied Columns For Square Sections.

\begin{tabular}{|c|c|c|c|c|c|c|c|c|c|c|}
\hline $\begin{array}{l}\text { Column No. } \\
\text { designation }\end{array}$ & End condition & $\begin{array}{c}\text { Shape of } \\
\text { cross } \\
\text { section }\end{array}$ & $\begin{array}{l}\text { Grade of } \\
\text { concrete fcu } \\
\mathrm{kg} / \mathrm{cm}^{2}\end{array}$ & $\begin{array}{l}\text { Percent } \\
\text { Reinf. } \\
\mu_{s}(\%)\end{array}$ & $\begin{array}{c}\text { Volumetri } \\
\text { c ratio } \\
\rho_{\mathrm{s}}(\%)\end{array}$ & $f_{\mathrm{cc}}\left(\mathrm{kg} / \mathrm{cm}^{2}\right)$ & $f_{\mathrm{cl}}\left(\mathrm{kg} / \mathrm{cm}^{2}\right)$ & $\begin{array}{l}\varepsilon_{\mathrm{cc}} \times 10^{-5} \\
(\mathrm{~cm} / \mathrm{cm})\end{array}$ & $\begin{array}{l}\varepsilon_{\mathrm{cl}} \times 10^{-5} \\
(\mathrm{~cm} / \mathrm{cm})\end{array}$ & $\begin{array}{l}\varepsilon_{\mathrm{cc}} \mathrm{x} 10^{-5} \\
(\mathrm{~cm} / \mathrm{cm})\end{array}$ \\
\hline C49 & Fixed-free & \multirow{24}{*}{ 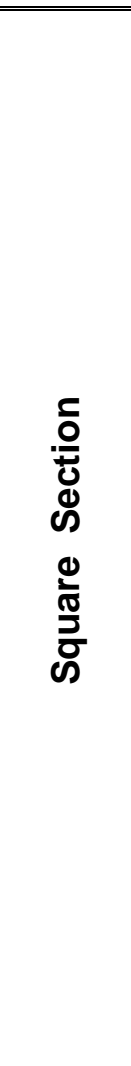 } & 300 & 1.61 & 0 & 240.0 & 66.86 & 60.3 & 17.9 & 71.0 \\
\hline $\mathrm{C} 50$ & Fixed-free & & 300 & 1.61 & 1.023 & 332.95 & 148.28 & 31.4 & 29.1 & 112.0 \\
\hline C51 & Fixed-free & & 300 & 1.61 & 1.6225 & 401.36 & 229.49 & 128.0 & 38.1 & 275.0 \\
\hline C52 & Fixed-free & & 300 & 1.61 & 2.70 & 448.125 & 240.61 & 134.0 & 39.8 & 350.0 \\
\hline C53 & Fixed-free & & 600 & 1.61 & 0 & 492.05 & 151.19 & 183.0 & 54.30 & 203.0 \\
\hline C54 & Fixed-free & & 600 & 1.61 & 1.023 & 670.803 & 180.53 & 220.0 & 71.20 & 320.0 \\
\hline C55 & Fixed-free & & 600 & 1.61 & 1.6225 & 815.628 & 375.61 & 310.0 & 92.0 & 372.0 \\
\hline C56 & Fixed-free & & 600 & 1.61 & 2.70 & 820.272 & 346.8 & 343.0 & 102.0 & 410.0 \\
\hline C57 & Fixed-free & & 900 & 1.61 & $\overline{0}$ & 693.95 & 196.05 & 187.0 & 85.3 & 195.0 \\
\hline C58 & Fixed-free & & 900 & 1.61 & 1.023 & 949.74 & 289.11 & 290.0 & 83.20 & 310.0 \\
\hline C59 & Fixed-free & & 900 & 1.61 & 1.6225 & 1135.68 & 392.67 & 409.0 & 121.5 & 437.0 \\
\hline C60 & Fixed-free & & 900 & 1.61 & 2.70 & 1162.13 & 442.06 & 450.0 & 133.0 & 480.0 \\
\hline C61 & Fixed-fixed & & 300 & 1.7 & 0.6 & 4430.95 & $204 ., 46$ & 346.0 & 261.0 & 367.0 \\
\hline C62 & Hinged-hinged & & 300 & 1.7 & 0.6 & 237.97 & 214.89 & 299.0 & 291.0 & 340.0 \\
\hline C63 & Fixed-hinged & & 300 & 1.7 & 0.6 & 325.08 & 54.98 & 265.0 & 78.0 & 341.0 \\
\hline C64 & Fixed-free & & 300 & 1.7 & 0.6 & 337.15 & 90.72 & 169.0 & 68.9 & 200.0 \\
\hline C65 & Fixed-fixed & & 600 & 1.7 & 0.6 & 821.63 & 229.53 & 326.0 & 281.0 & 361.0 \\
\hline C66 & Hinged-hinged & & 600 & 1.7 & 0.6 & 775.87 & 232.67 & 304.0 & 311.0 & 364.0 \\
\hline C67 & Fixed-hinged & & 600 & 1.7 & 0.6 & 625.17 & 105.83 & 281.0 & 248.0 & 348.0 \\
\hline C68 & Fixed-free & & 600 & 1.7 & 0.6 & 743.2 & 185.82 & 211.0 & 87.0 & 294.0 \\
\hline C69 & Fixed-fixed & & 900 & 1.7 & 0.6 & 1078.35 & 273.28 & 307.0 & 299.0 & 370.0 \\
\hline $\mathrm{C70}$ & Hinged-hinged & & 900 & 1.7 & 0.6 & 1147.78 & 268.19 & 309.0 & 303.0 & 356.0 \\
\hline C71 & Fixed-hinged & & 900 & 1.7 & 0.6 & 1108.66 & 129.61 & 296.0 & 117.0 & 320.0 \\
\hline $\mathrm{C} 72$ & Fixed-free & & 900 & 1.7 & 0.6 & 1070.7 & 176.89 & 254.0 & 108.0 & 274.0 \\
\hline
\end{tabular}



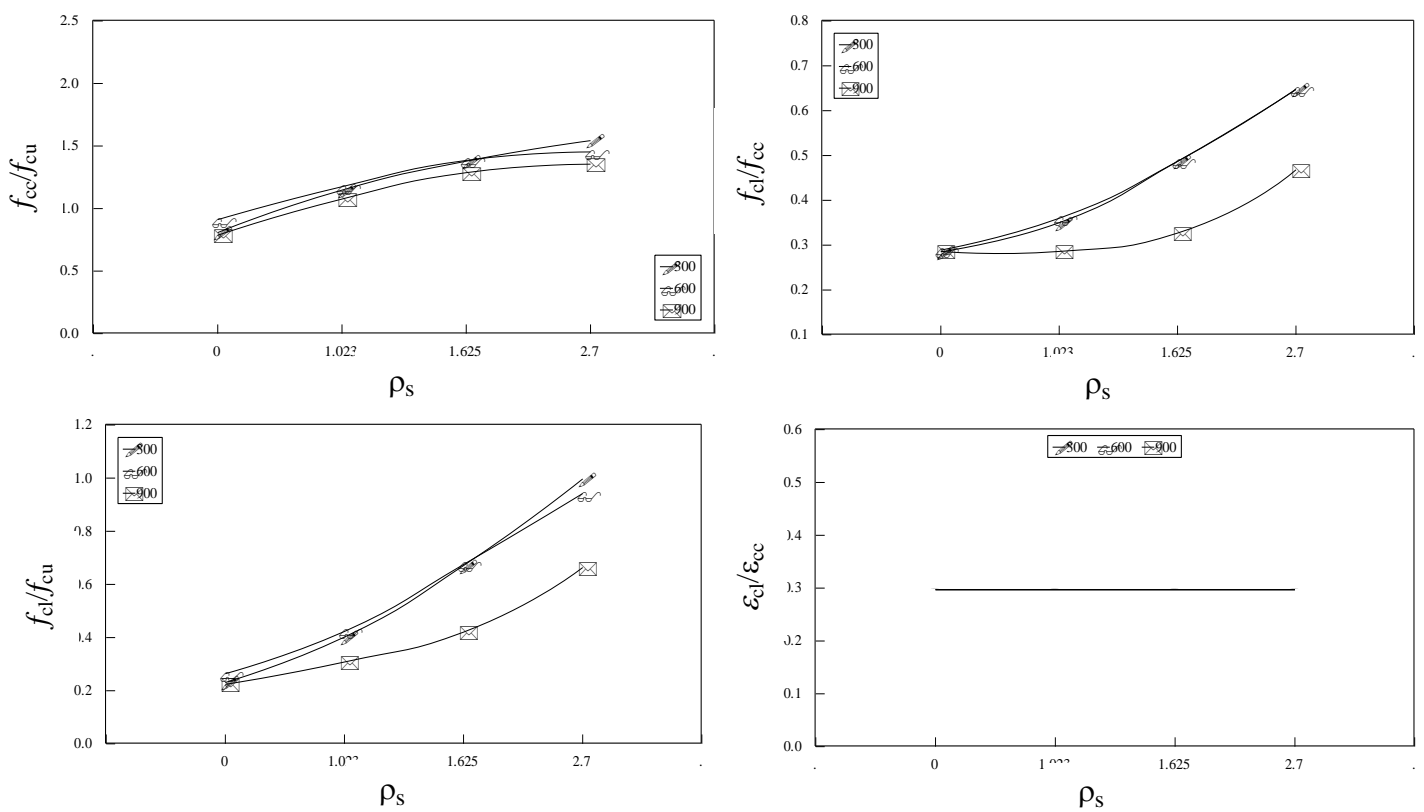

Fig.16: Effect of volumetric ratio $\left(\rho_{\mathrm{s}} \%\right)$ on the ratios of the inducea maximum stress and strains for axial R.C columns for different shapes of cross-section with constant end condition (fixed-free) for rectangular columns.
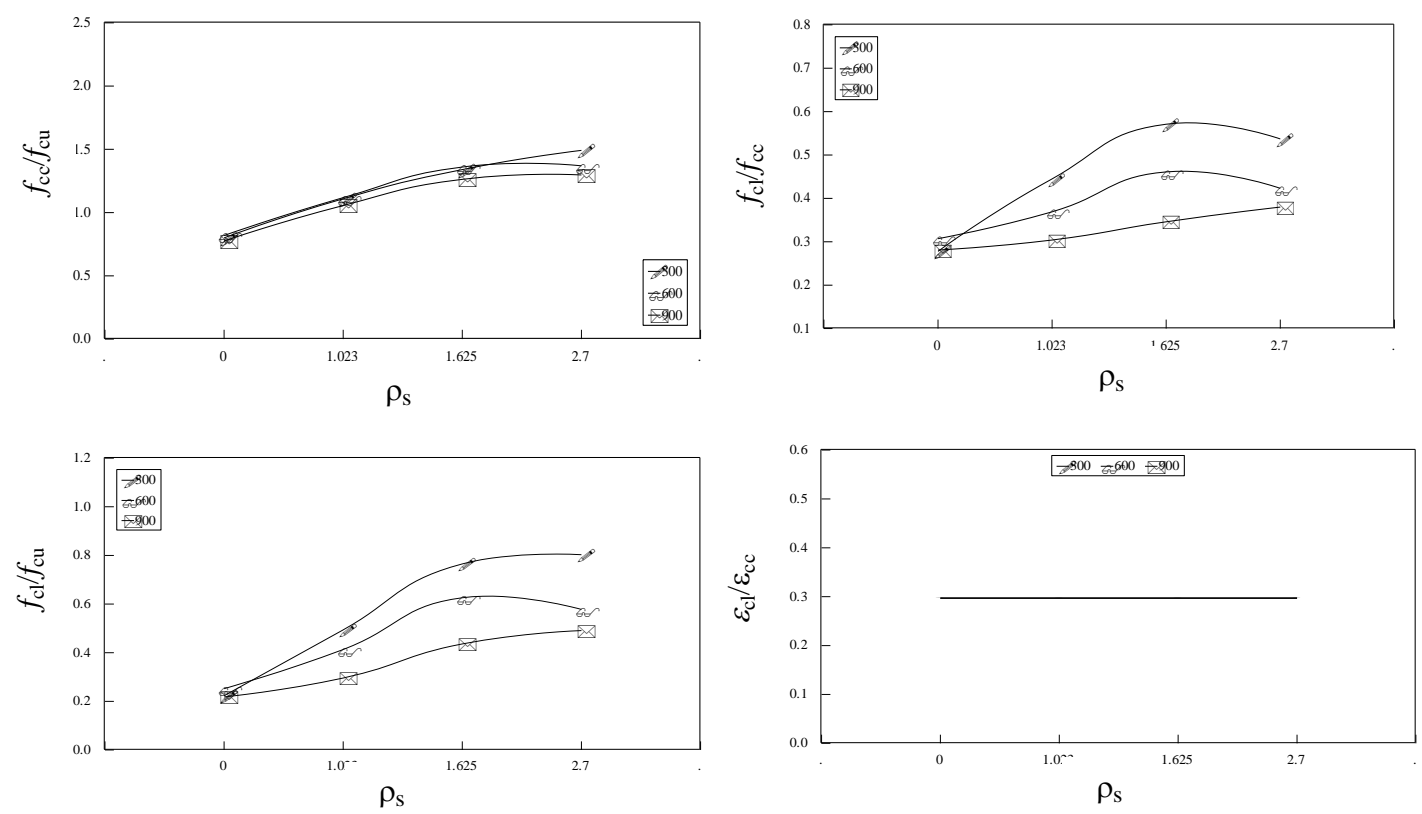

Fig.17: Effect of volumetric ratio $\left(\rho_{\mathrm{s}} \%\right)$ on the ratios of the induced maximum stress and strains for axial R.C columns for different shapes of cross-section with constant end condition (fixed-free) for square columns. 


\section{Effect of Boundary Condition on the Induced Maximum Stresses and Strains}

Figures (18) (19) and (20) show how the end boundary condition affects the induced axial stresses, lateral stresses and lateral strains for axial columns for different grades of concrete with constant volumetric ratio $\left(\rho_{\mathrm{s}}=0.6 \%\right)$. Such effect is shown in Figs. (21), (22) and (23).

Examination of previous figures led to the following observation:

- The highest ratio of $\left(f_{\mathrm{cc}} / f_{\mathrm{cu}}\right)$, for $\left(f_{\mathrm{cu}}=300\right.$ and $\left.600 \mathrm{~kg} / \mathrm{cm}^{2}\right)$ was obtained at (hinged-hinged) end condition however for $\left(f_{\mathrm{cu}}=900 \mathrm{~kg} / \mathrm{cm}^{2}\right)$ it was obtained at (fixed-hinged) end condition.

- The highest ratio of the maximum value $\left(f_{\mathrm{c}} / f_{\mathrm{cc}}\right)$ was obtained at (fixedfixed) end condition for grade of concrete $\left(f_{\mathrm{cu}}=600 \mathrm{~kg} / \mathrm{cm}^{2}\right)$.

- The highest ratio of the maximum value $\left(f_{\mathrm{c}} \mathrm{l} f_{\mathrm{cu}}\right)$ was obtained at (fixedfixed) end condition, for grade of concrete $\left(f_{\mathrm{cu}}=600 \mathrm{~kg} / \mathrm{cm}^{2}\right)$.

- The highest ratio of the maximum value $\left(\varepsilon_{\mathrm{cl}} / \varepsilon_{\mathrm{cc}}\right)$ was obtained at (fixedfree) end condition, for grade of concrete $\left(f_{\mathrm{cu}}=900 \mathrm{~kg} / \mathrm{cm}^{2}\right)$.

\section{Finally the following can be summarized:}

The highest ratio of the maximum value $\left(f_{\mathrm{cc}} / f_{\mathrm{cu}}\right)$ was obtained at (fixed-hinged) end condition, for grade of concrete $\left(f_{\mathrm{cu}}\right)=900 \mathrm{~kg} / \mathrm{cm}^{2}$. The highest ratio of the maximum value $\left(f_{\mathrm{cl}} / f_{\mathrm{cc}}\right)$ was obtained at both (fixed-hinged) and (hinged-hinged) end condition for grade of concrete $\left(f_{\mathrm{cu}}=300,600 \mathrm{~kg} / \mathrm{cm}^{2}\right)$. The highest ratio of the maximum value $\left(f_{\mathrm{cl}} / f_{\mathrm{cu}}\right)$ was obtained at (fixed-hinged) end condition for grades of concrete $\left(f_{\mathrm{cu}}=300\right.$ $\left.\mathrm{kg} / \mathrm{cm}^{2}\right)$.The highest ratio of the maximum value $\left(\varepsilon_{\mathrm{c}} / \varepsilon_{\mathrm{cc}}\right)$ was obtained at (fixed-fixed) end condition for grade of concrete $\left(f_{\mathrm{cu}}=300 \mathrm{~kg} / \mathrm{cm}^{2}\right)$.

The highest ratio of the maximum value $\left(f_{\mathrm{cc}} / f_{\mathrm{cu}}\right)$ was obtained at (fixed-fixed) end condition for grade of concrete $\left(f_{\mathrm{cu}}=300 \mathrm{~kg} / \mathrm{cm}^{2}\right)$. The highest ratio of the maximum value $\left(f_{\mathrm{cl}} / f_{\mathrm{cc}}\right)$ was obtained at (fixed-fixed) end condition for grade of concrete $\left(f_{\mathrm{cu}}=300 \mathrm{~kg} / \mathrm{cm}^{2}\right)$. The highest ratio of the maximum value $\left(f_{\mathrm{cl}} / f_{\mathrm{cu}}\right)$ was obtained at (hinged-hinged) end condition, for grade of concrete $\left(f_{\mathrm{cu}}=300 \mathrm{~kg} / \mathrm{cm}^{2}\right)$. The highest ratio of the maximum value $\left(\varepsilon_{\mathrm{cl}} / \varepsilon_{\mathrm{cc}}\right)$ was obtained at (hinged-hinged) end condition for grade of concrete $\left(f_{\mathrm{cu}}\right)=900 \mathrm{~kg} / \mathrm{cm}^{2}$. 

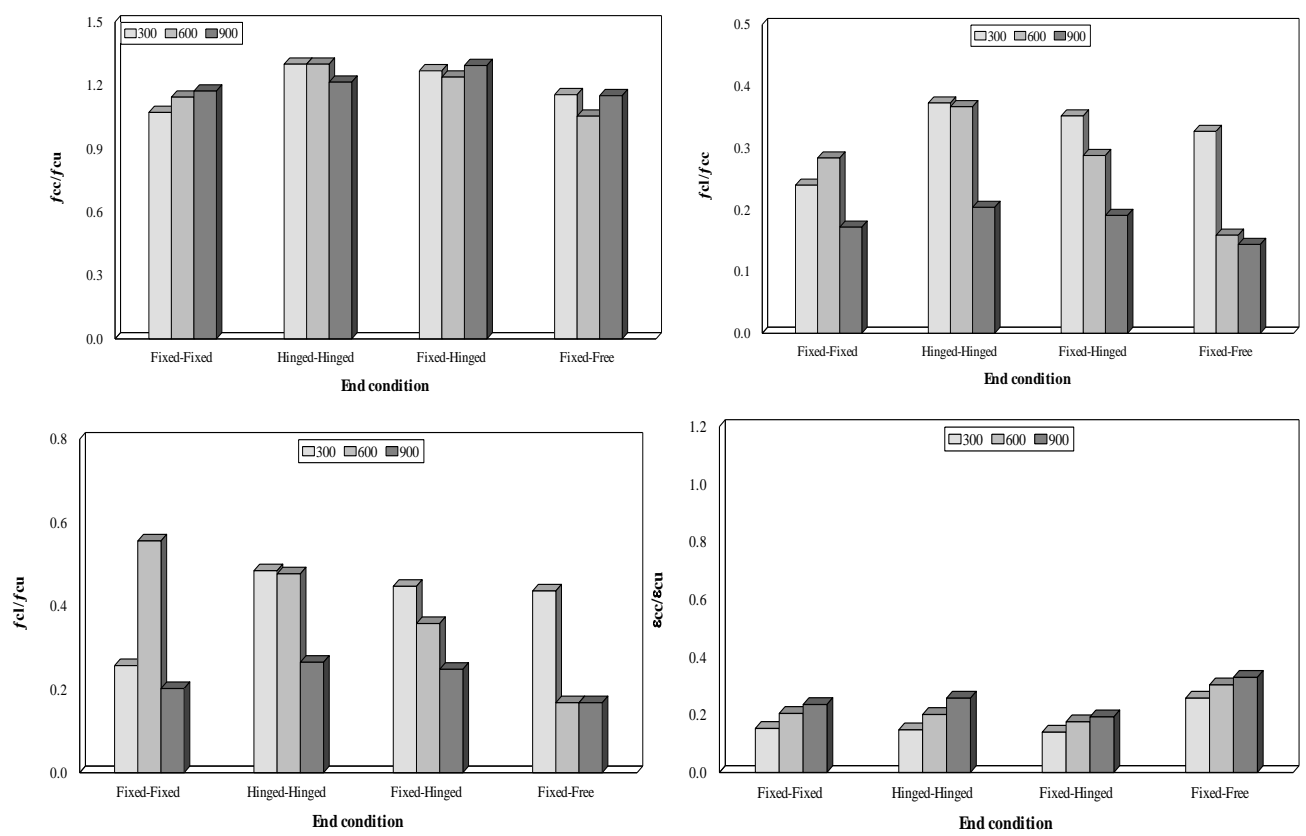

Fig.18: Effect of end boundary condition on the induced ratios of the maximum stress and strains for axial R.C columns for different Grades of concrete with constant volumetric ratio $\left(\rho_{\mathrm{s}}=0.6 \%\right)$ for circular columns.
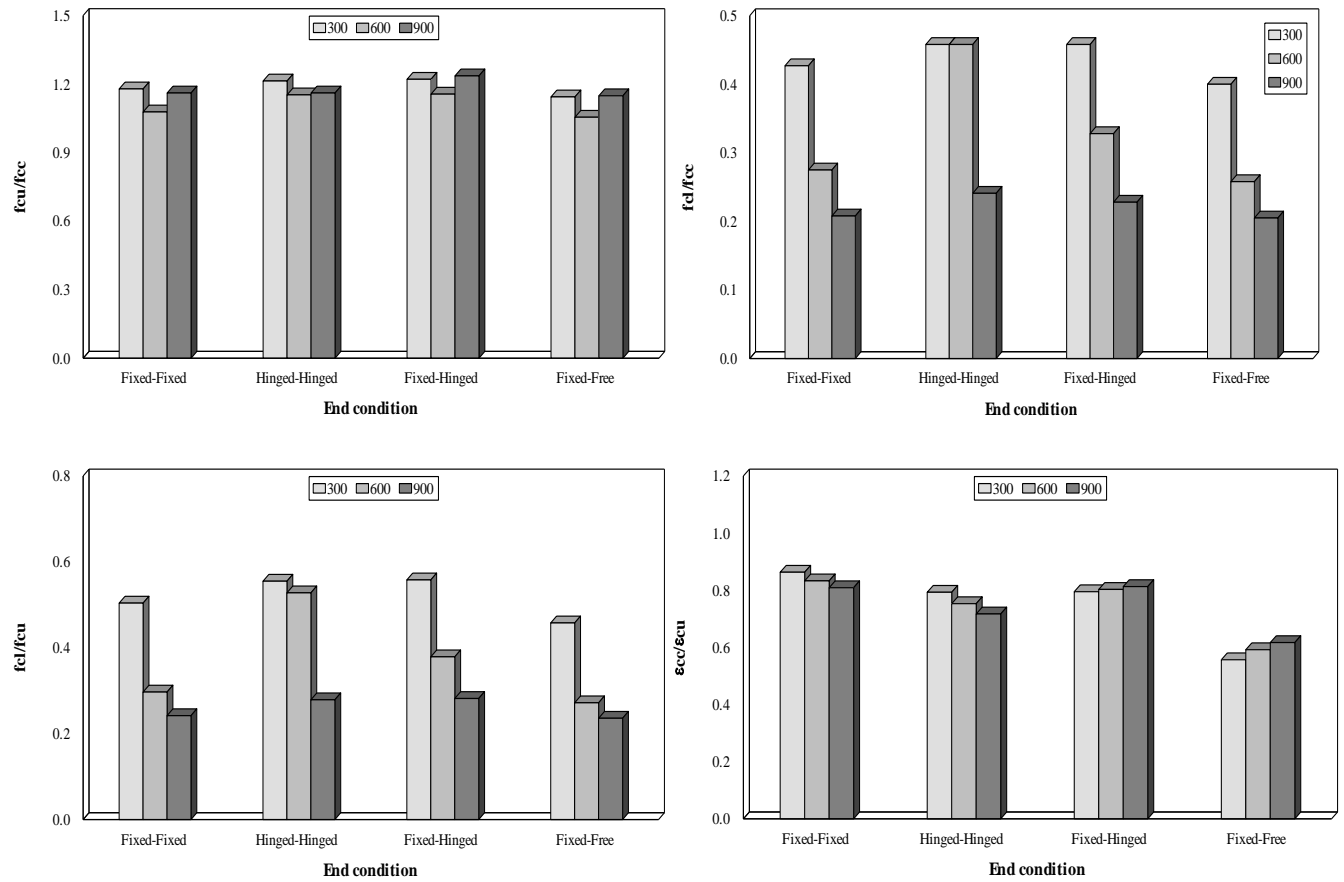

Fig.19: Effect of end boundary condition on the induced ratios of the maximum stress and strains for axial R.C columns for different Grades of concrete with constant volumetric ratio $\left(\rho_{\mathrm{s}}=0.6 \%\right)$ for rectangular columns. 

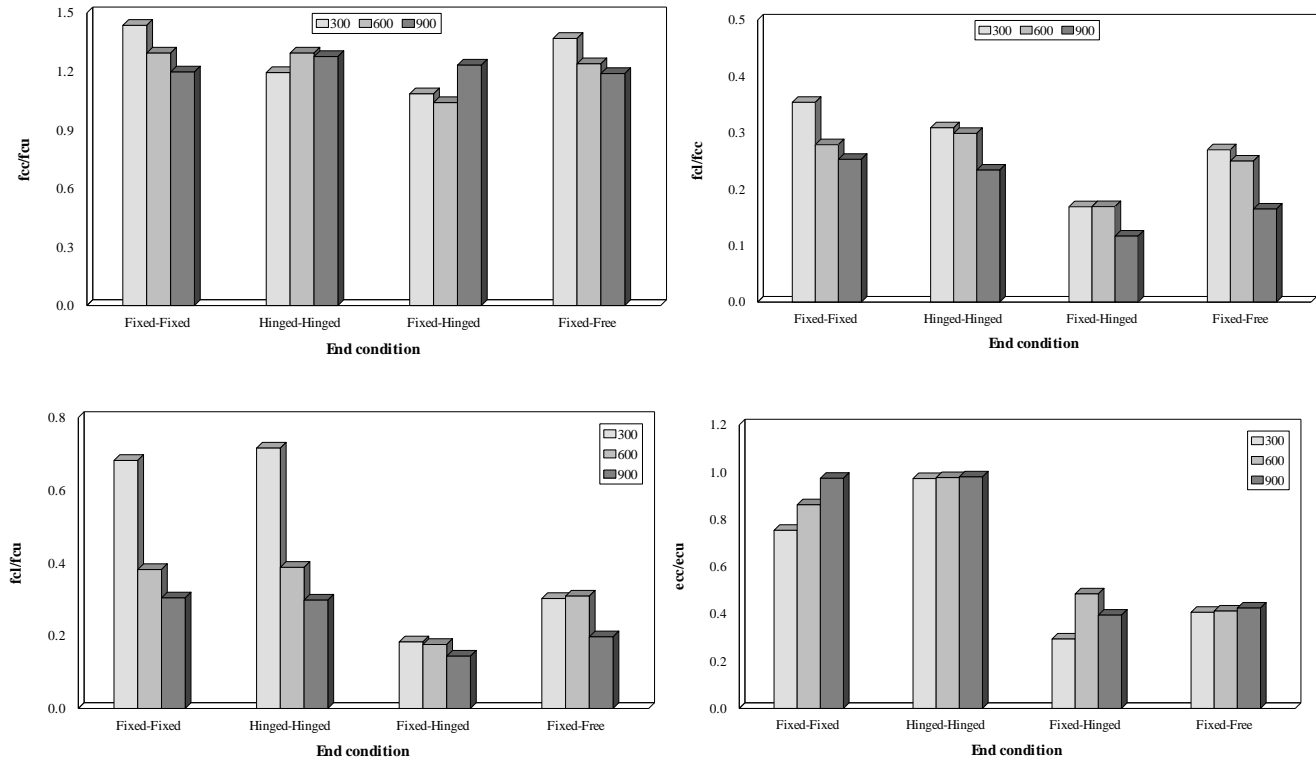

Fig.20: Effect of end boundary condition on the induced ratios of the maximum stress and strains for axial R.C columns for different Grades of concrete with constant volumetric ratio $\left(\rho_{\mathrm{s}}=0.6 \%\right)$ for square columns.
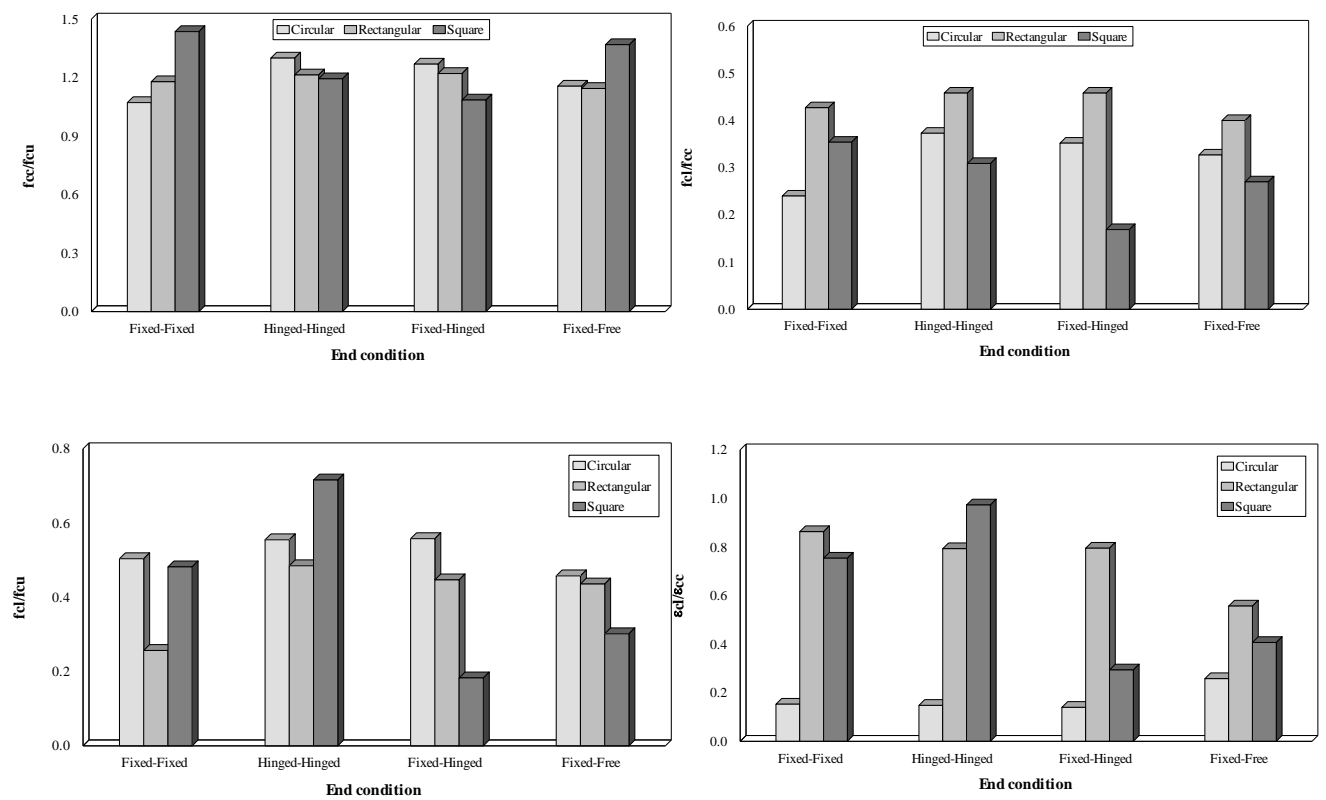

Fig.21: Effect of shape of cross-section on the ratios of the induced maximum stresses and strains for axial R.C columns for different and condition (fixed-fixed, hinge-hinged, fixed-hinged and fixed-free) with constant volumetric ratio ( $\rho s=0.6 \%$ ) for concrete grade $\mathrm{C} 300$. 

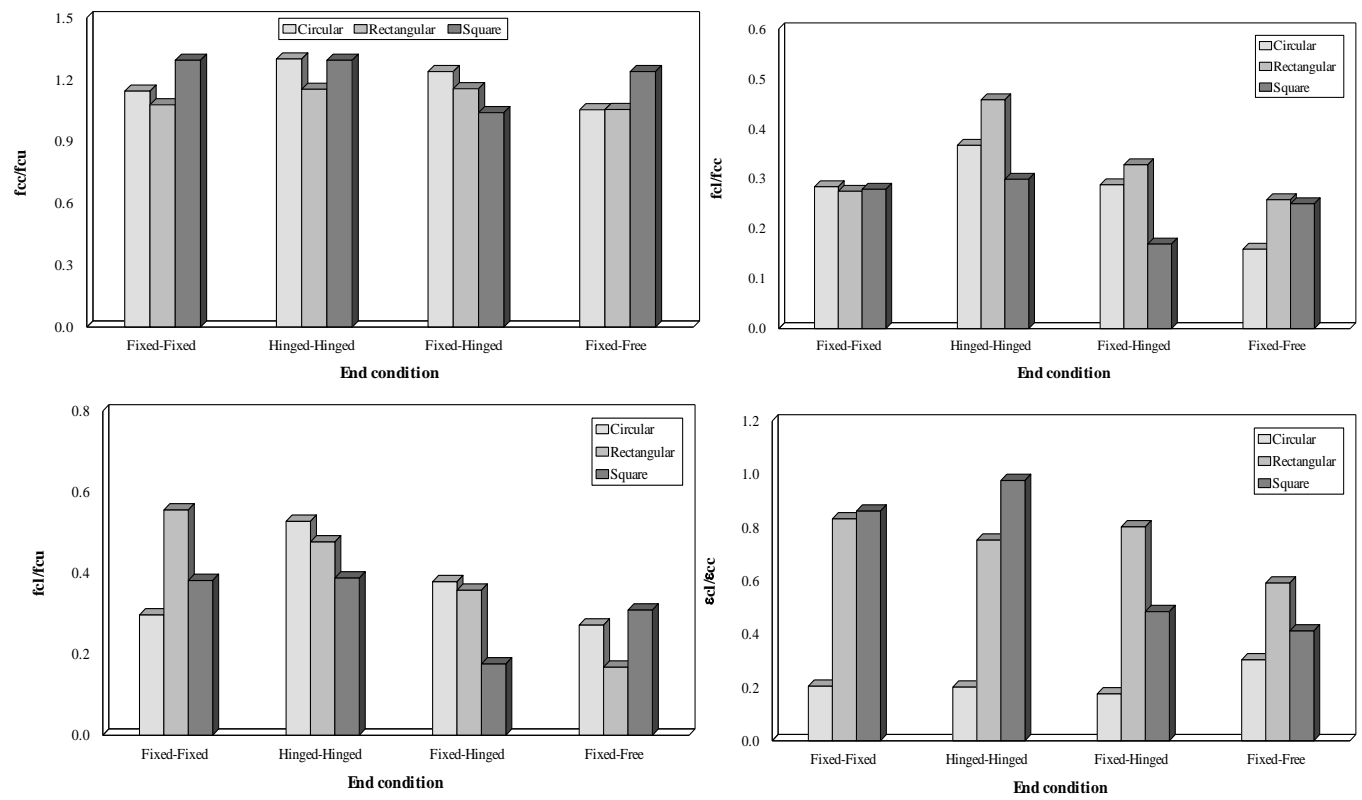

Fig.22: Effect of shape of cross-section on the ratios of the induced maximum stresses and strains for axial R.C columns for different and condition (fixed-fixed, hinge-hinged, fixed-hinged and fixed-free) with constant volumetric ratio $(\rho s=0.6 \%)$ for concrete grade C600.
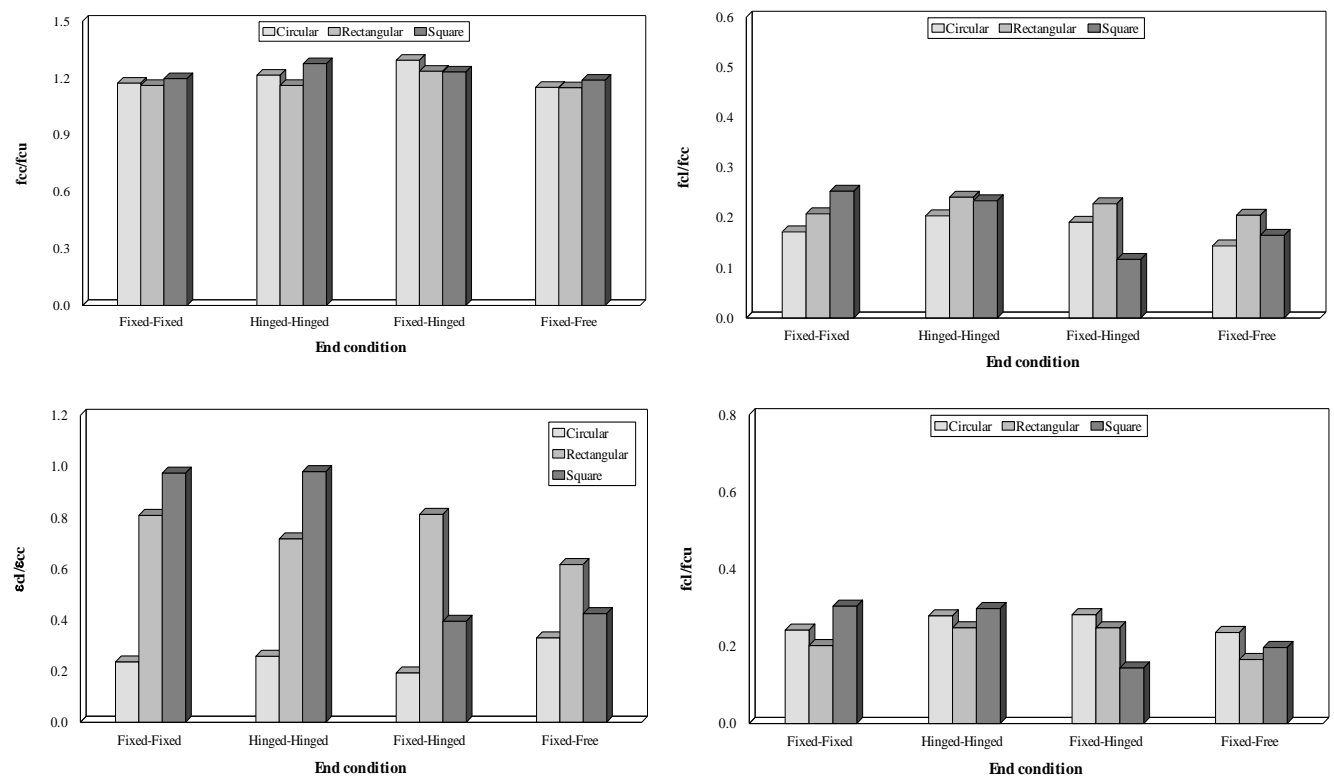

Fig.23: Effect of shape of cross-section on the ratios of the induced maximum stresses and strains for axial R.C columns for different and condition (fixed-fixed, hinge-hinged, fixed-hinged and fixed-free) with constant volumetric ratio ( $\rho s=0.6 \%)$ for concrete grade $\mathrm{C} 900$. 

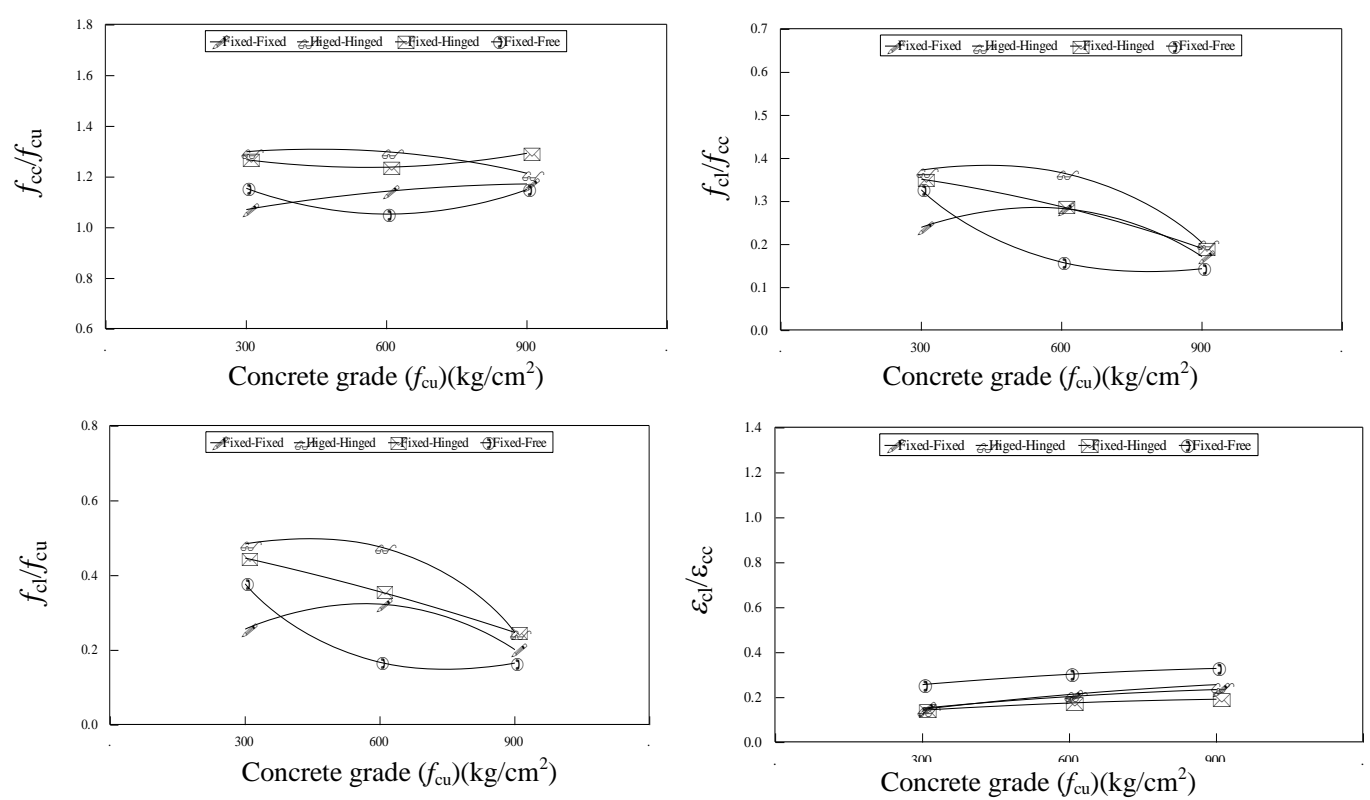

Fig.24: Effect of concrete grade on the induced ratios of the maximum stress and strains for axial R.C columns for different end condition (fixed-fixed, hinged-hinged, fixed-hinged and fixed-free) with constant volumetric ratio $\left(\rho_{\mathrm{s}}=0.6 \%\right)$ for circular columns.
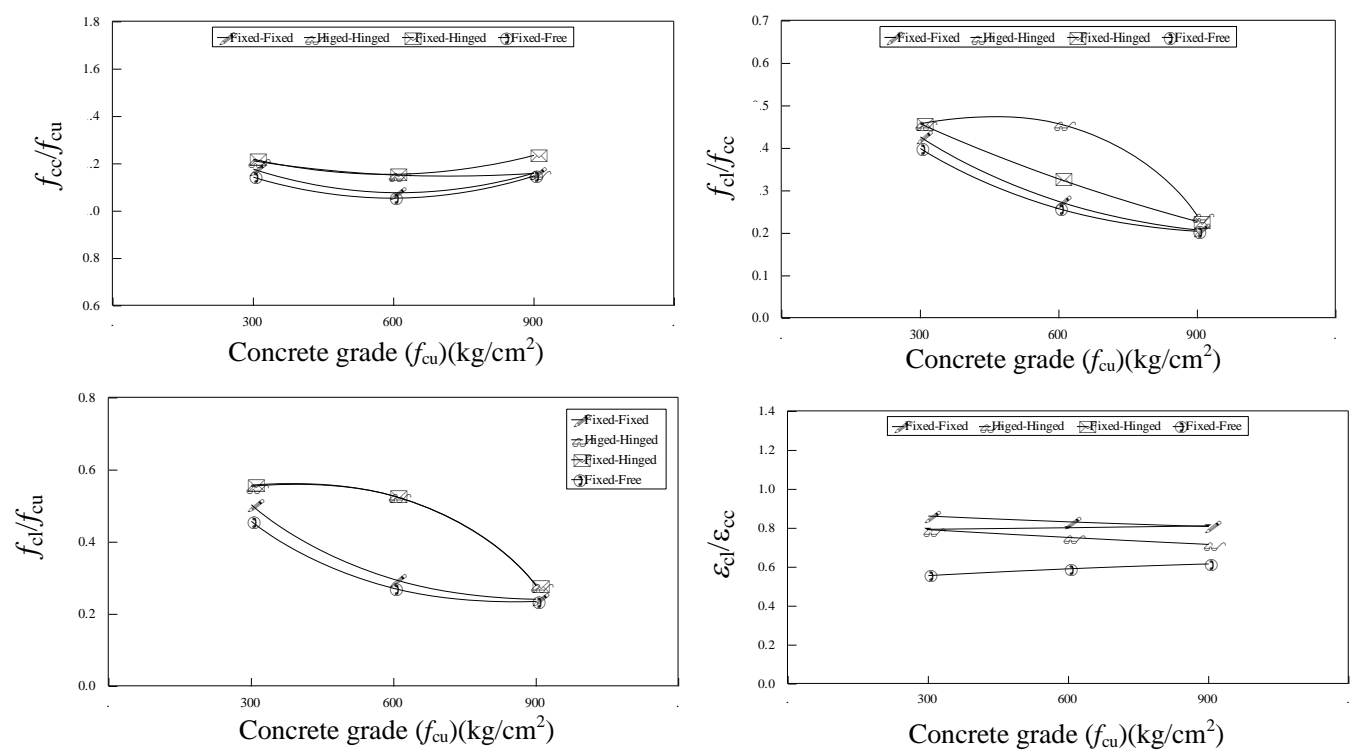

Fig.25: Effect of concrete grade on the induced ratios of the maximum stress and strains for axial R.C columns for different end condition (fixed-fixed, hinged-hinged, fixed-hinged and fixed-free) with constant volumetric ratio $\left(\rho_{\mathrm{s}}=0.6 \%\right)$ for rectangular columns. 

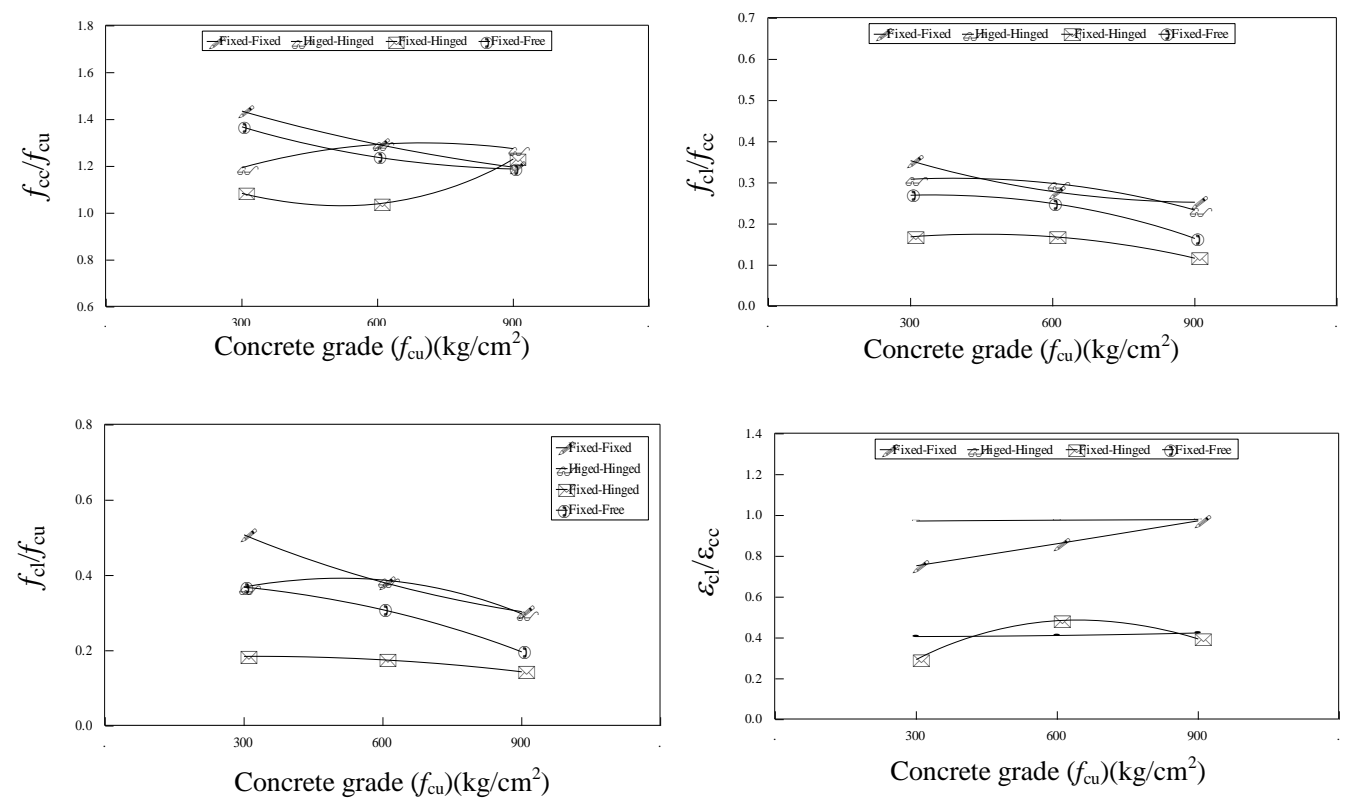

Fig.26: Effect of concrete grade on the induced ratios of the maximum stress and strains for axial R.C columns for different end condition (fixed-fixed, hinged-hinged, fixed-hinged and fixed-free) with constant volumetric ratio $\left(\rho_{\mathrm{s}}=0.6 \%\right)$ for square columns.

\section{Effect of Shape of Cross Section}

Figures (27), (28) and (29) declare the effect of shape of cross-section (circularrectangular and square) on the induced maximum stresses and strains for different used volumetric ratios $\left(\rho_{\mathrm{s}} \%\right)$ for the case of used constant grades with (fixed-free) end condition. From the previous figures the following important remarks are given:

For a given grade of concrete and constant cross-section shape with constant end condition, the induced maximum axial stresses $\left(f_{\mathrm{cc}}\right)$, the induced maximum lateral stresses $\left(f_{\mathrm{cl}}\right)$ well as the induced lateral strains $\left(\varepsilon_{\mathrm{cl}}\right)$ increases with the increase of volumetric ratio $\left(\rho_{\mathrm{s}} \%\right)$. The rate of increase mainly depends on both the shape of cross-sections and grade of concrete. The rate of increase of the induced maximum axial and lateral stresses is higher for lower used grade of concrete (300) with the order circular, rectangular and square sections respectively. 

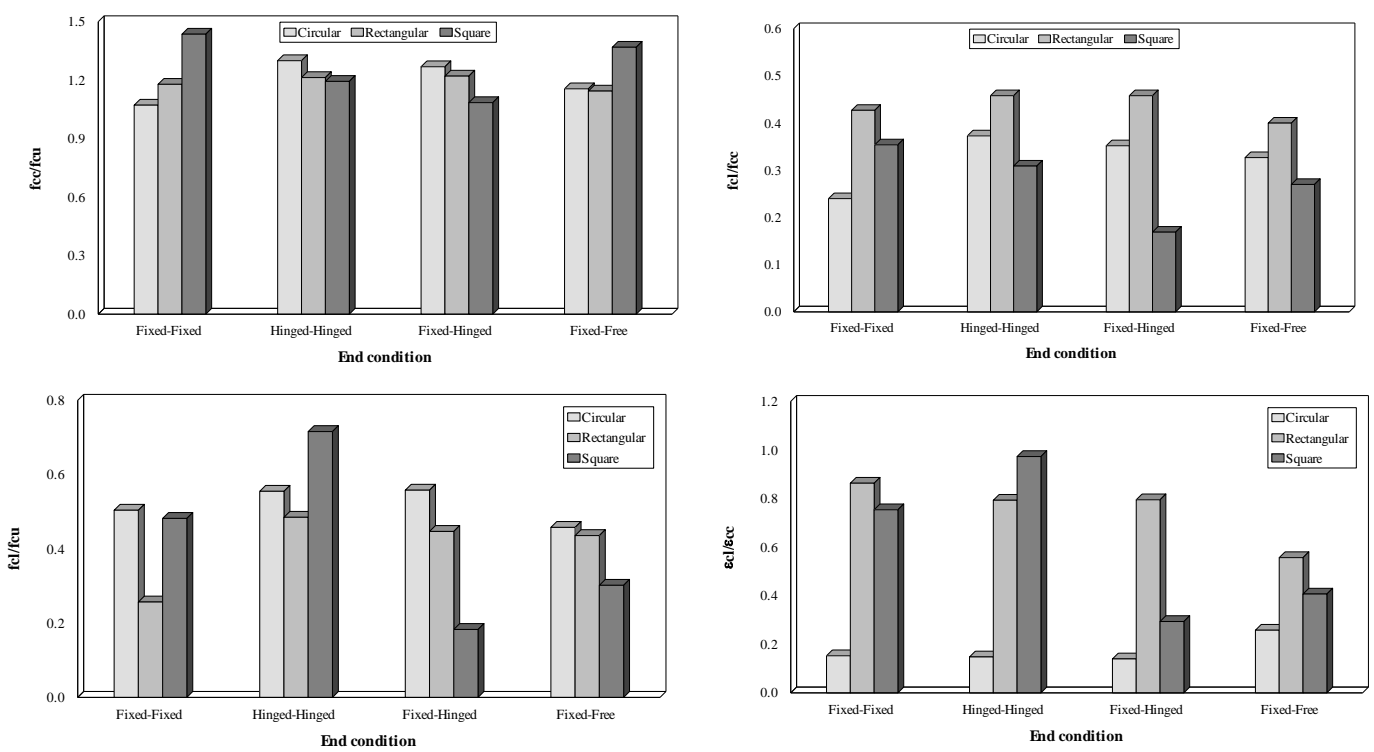

Fig.27: Effect of shape of cross-section on the ratios of the induced maximum stresses and strains for axial R.C columns for different and condition (fixed-fixed, hinge-hinged, fixed-hinged and fixed-free) with constant volumetric ratio ( $\rho s=0.6 \%)$ for concrete grade $\mathrm{C} 300$.
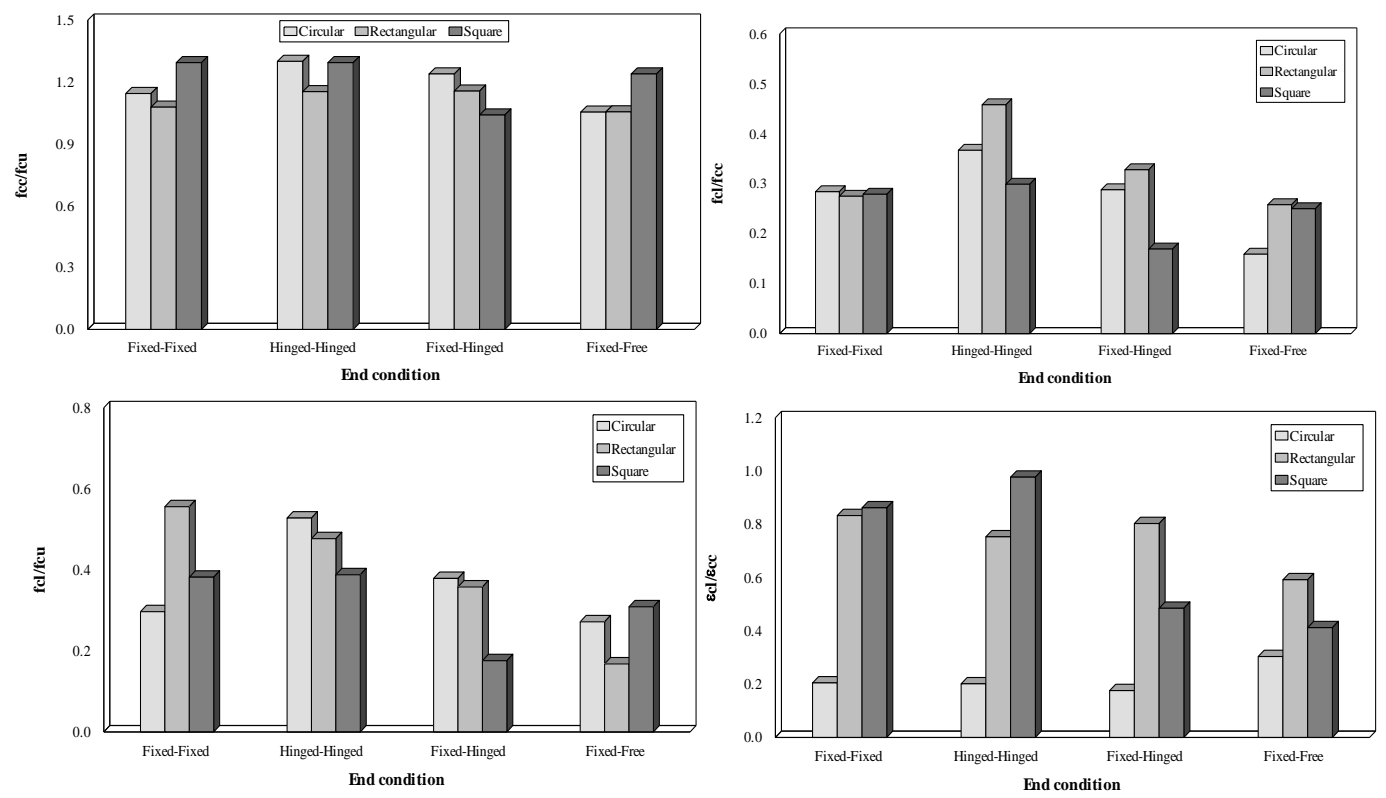

Fig.28: Effect of shape of cross-section on the ratios of the induced maximum stresses and strains for axial R.C columns for different and condition (fixed-fixed, hinge-hinged, fixed-hinged and fixed-free) with constant volumetric ratio $(\rho s=0.6 \%)$ for concrete grade C600. 

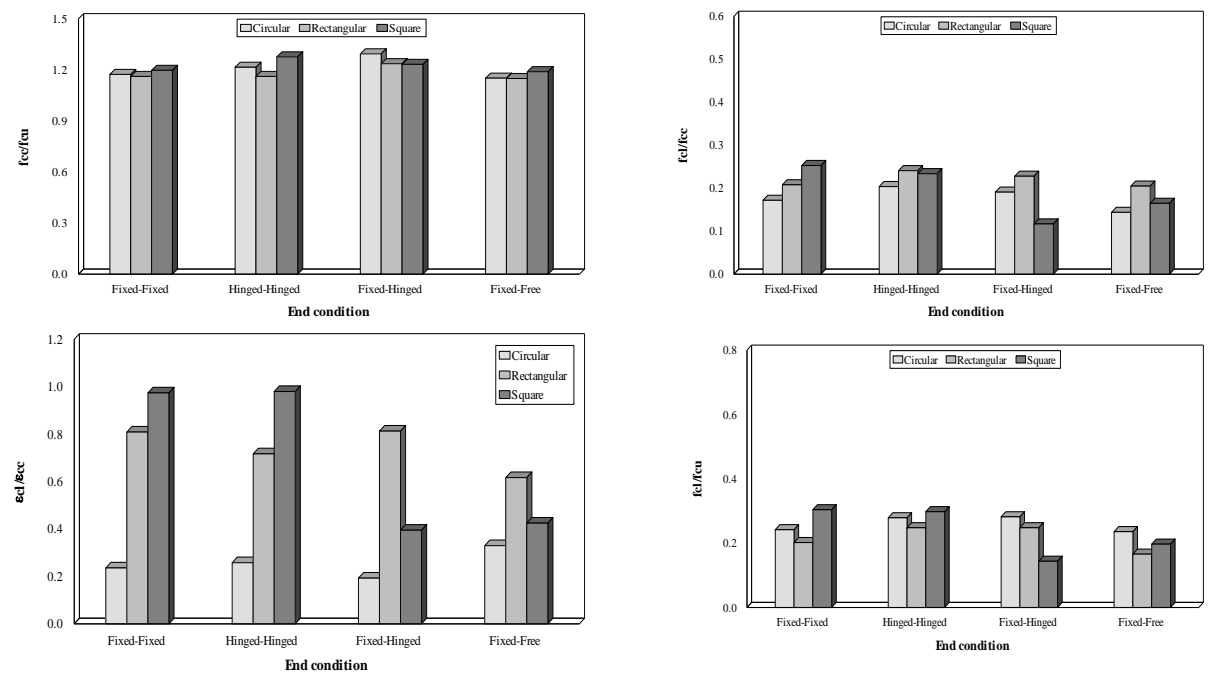

Fig.29: Effect of shape of cross-section on the ratios of the induced maximum stresses and strains for axial R.C columns for different and condition (fixed-fixed, hinge-hinged, fixedhinged and fixed-free) with constant volumetric ratio $(\rho s=0.6 \%)$ for concrete grade C 900 .

\section{Effect of Grade of Concrete:}

Figures (30), (31) and (32) indicate the effect of the concrete grade $\left(f_{\text {cu }}\right)$ on the induced maximum axial stresses, lateral stresses and lateral strains for axial R.C columns at different volumetric ratios $\left(\rho_{\mathrm{s}} \%\right)$ with different shapes of cross-sections for constant end conditions (fixed-free).
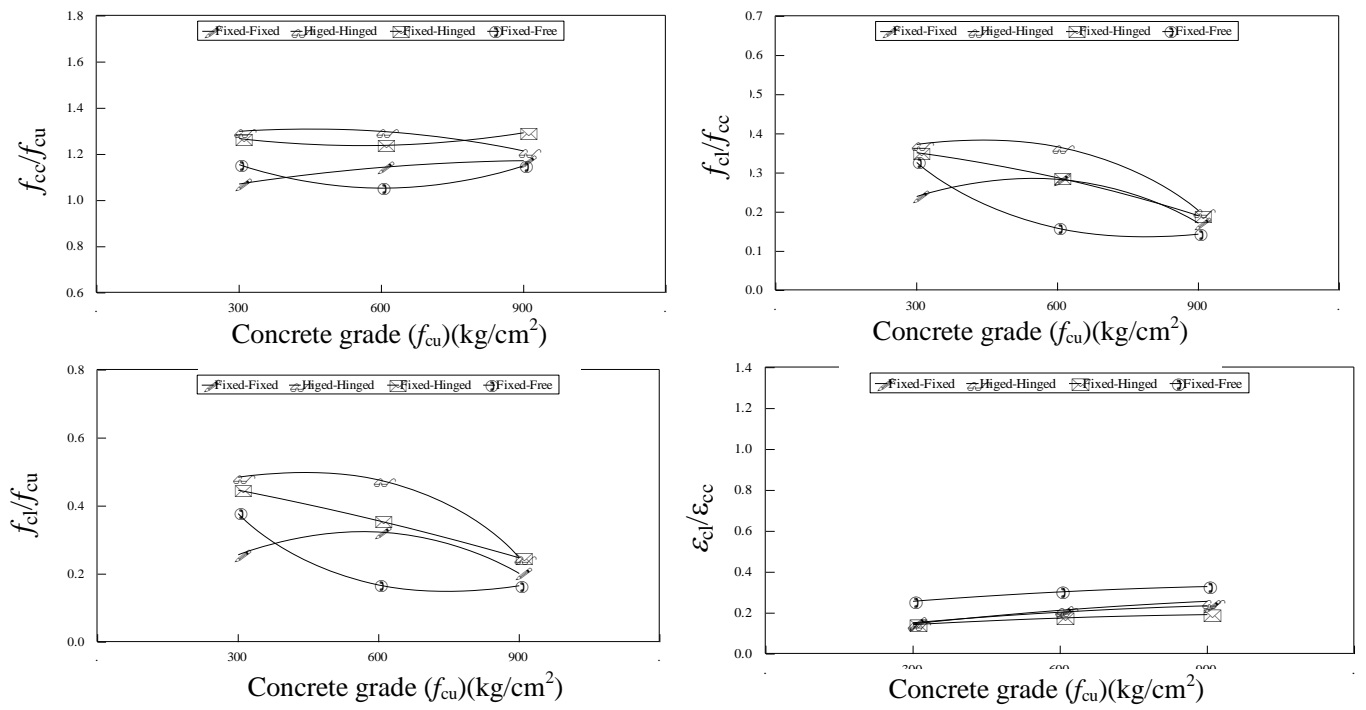

Fig.(30): Effect of concrete grade on the induced ratios of the maximum stress and strains for axial R.C columns for different end condition (fixed-fixed, hinged-hinged, fixed-hinged and fixed-free) with constant volumetric ratio $\left(\rho_{\mathrm{s}}=0.6 \%\right)$ for circular columns. 

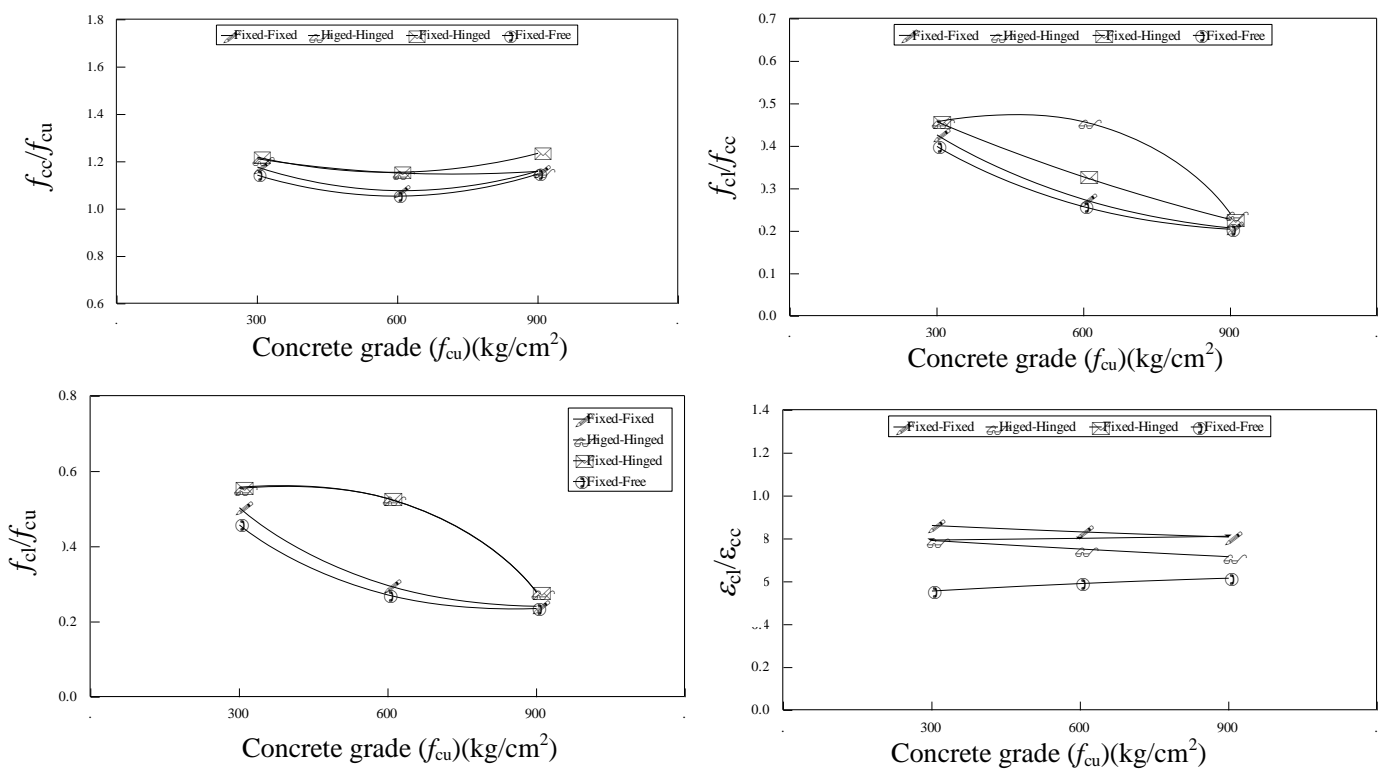

Fig.(31): Effect of concrete grade on the induced ratios of the maximum stress and strains for axial R.C columns for different end condition (fixed-fixed, hinged-hinged, fixed-hinged and fixed-free) with constant volumetric ratio $\left(\rho_{\mathrm{s}}=0.6 \%\right)$ for rectangular columns.
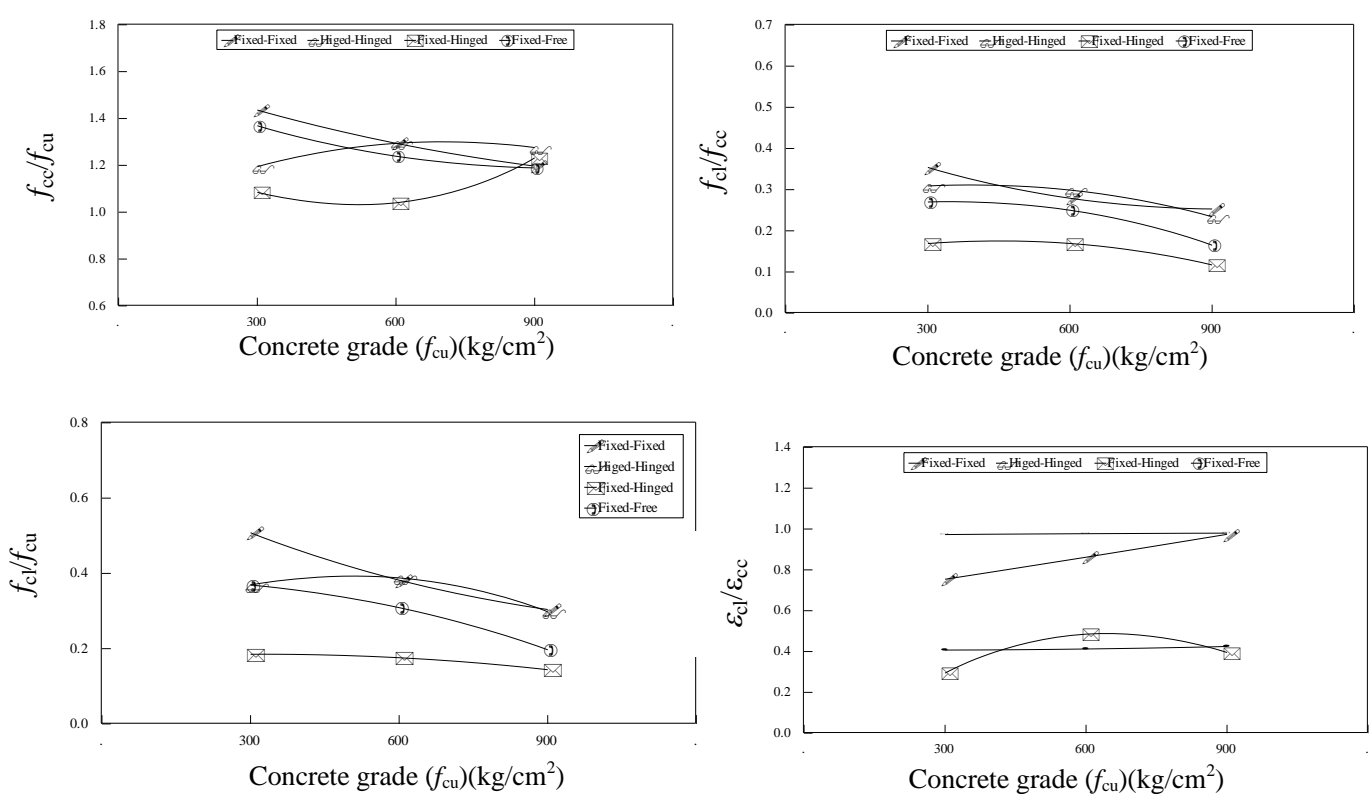

Fig.(32): Effect of concrete grade on the induced ratios of the maximum stress and strains for axial R.C columns for different end condition (fixed-fixed, hinged-hinged, fixed-hinged and fixed-free) with constant volumetric ratio $\left(\rho_{\mathrm{s}}=0.6 \%\right)$ for square columns. 


\section{CONCLUSIONS}

1. For a given grade of concrete and constant cross-section shape with constant end condition, the induced maximum axial stresses $\left(f_{\mathrm{cc}}\right)$, the induced maximum lateral stresses $\left(f_{\mathrm{cl}}\right)$, the induced lateral strains $\left(\varepsilon_{\mathrm{cl}}\right)$ increases with the increase of volumetric ratio $\left(\rho_{\mathrm{s}} \%\right)$. The rate of increase mainly depends on both the shape of cross-sections and grade of concrete. The rate of increase of the induced maximum axial and lateral stresses is higher for lower used grade of concrete (300) with the order circular, rectangular and square sections respectively.

2. For columns confined with $0,1.023,1.6225$ and $2.7 \%$ volumetric ratios, with fixed-free end condition, either grade of concrete 300,600, $900 \mathrm{kglcm} 2$ for different cross sections (circular, rectangular and square), the strength ratio of $\left(f_{\mathrm{cc}} / f_{\mathrm{cu}}\right)\left(f_{\mathrm{cl}} / f_{\mathrm{cc}}\right)\left(f_{\mathrm{cl}} / f_{\mathrm{cu}}\right)$ increases with increase of volumetric ratio ( $\rho$ s). Strength ratio $\left(f_{\mathrm{cc}} / f_{\mathrm{cu}}\right)$ increases with $78.85 \%$ for circular columns, $75.28 \%$ for rectangular columns and $73.75 \%$ for square columns. This means that strength ratio of $\left(f_{\mathrm{cd}} / f_{\mathrm{cu}}\right)$ increases for columns confined for circular column than rectangular columns with $1.05 \%$ and rectangular than that for square columns with $1.02 \%$. For lateral strength ratio $\left(f_{\mathrm{cl}} / f_{\mathrm{cc}}\right)$ increases with $73.32 \%$ for circular columns with $68.45 \%$ for rectangular columns and with $51.97 \%$ for square columns. This means that strength ratio of $\left(f_{\mathrm{cl}} / f_{\mathrm{cc}}\right)$ increases for columns confined for circular columns than that for rectangular columns with $1.07 \%$ and rectangular than square columns with $1.32 \%$. For lateral strength ratio $\left(f_{\mathrm{cl}} / f \mathrm{cu}\right)$ increases with $89.62 \%$ for circular columns. For rectangular columns, it increases with $89.16 \%$ and $87.0 \%$ for square columns. This means that strength ratio of $\left(f_{\mathrm{cl}} / f_{\mathrm{cu}}\right)$ increases for columns confined for circular columns rather than rectangular columns with $1.01 \%$ and for rectangular columns rather than square columns with $1.02 \%$.

3. The grade of concrete, $f_{\text {cu }}$, definitely affects both the induced maximum axial and lateral stresses $f_{\mathrm{cc}}, f_{\mathrm{cl}}$ which both increase $f_{\mathrm{cu}}$, and maximum value was obtained at circular columns confined with $2.7 \%$ volumetric ratio. The strength ratios $\left(f_{\mathrm{cc}} / f_{\mathrm{cu}}\right)\left(f_{\mathrm{cl}} / f_{\mathrm{cc}}\right)\left(f_{\mathrm{cl}} / f_{\mathrm{cu}}\right)$ decrease with increase of grade of concrete $f_{\mathrm{cu}}$. Strength ratio $\left(f_{\mathrm{cc}} / f_{\mathrm{cu}}\right)$ increases $18.46,9.98$ and 8.31 for circular, rectangular and square columns respectively. Strength ratio $\left(f_{\mathrm{cl}} / f_{\mathrm{cc}}\right)$ increases by 43.37, 37.68 and $43.49 \%$ for circular, rectangular and square columns respectively. Strength ratio $\left(f_{\mathrm{cl}} / f_{\mathrm{cu}}\right)$ decreases by $75.33,59.94$ and $64.79 \%$ for circular, rectangular and square columns respectively.

4. Concerning effect of boundary condition on the induced maximum stresses and strains, the highest ratio of the maximum value $\left(f_{\mathrm{cc}} / f_{\mathrm{cu}}\right)$ was obtained at (fixedhinged) end condition, for grade of concrete $\left(f_{\text {cu }}\right)=900 \mathrm{~kg} / \mathrm{cm}^{2}$. The highest ratio of the maximum value $\left(f_{\mathrm{c}} / f_{\mathrm{cc}}\right)$ was obtained at both (fixed-hinged) and (hingedhinged) end condition for grade of concrete $\left(f_{\mathrm{cu}}=300,600 \mathrm{~kg} / \mathrm{cm}^{2}\right)$. The highest ratio of the maximum value $\left(f_{\mathrm{c}} l f_{\mathrm{cu}}\right)$ was obtained at (fixed-hinged) end condition for grades of concrete $\left(f_{\mathrm{cu}}=300 \mathrm{~kg} / \mathrm{cm}^{2}\right)$. The highest ratio of the maximum value $\left(\varepsilon_{\mathrm{cl}} / \varepsilon_{\mathrm{cc}}\right)$ was obtained at (fixed-fixed) end condition for grade of concrete $\left(f_{\text {cu }}=300 \mathrm{~kg} / \mathrm{cm}^{2}\right)$. The highest ratio of the maximum value $\left(f_{\mathrm{cc}} / f_{\mathrm{cu}}\right)$ was obtained at (fixed-fixed) end condition for grade of concrete $\left(f_{\text {cu }}=300 \mathrm{~kg} / \mathrm{cm}^{2}\right)$. The highest ratio of the maximum value $\left(f_{\mathrm{cl}} / f_{\mathrm{cc}}\right)$ was obtained at (fixed-fixed) end 
condition for grade of concrete $\left(f_{\mathrm{cu}}=300 \mathrm{~kg} / \mathrm{cm}^{2}\right)$. The highest ratio of the maximum value $\left(f_{\mathrm{cl}} / f_{\mathrm{cu}}\right)$ was obtained at (hinged-hinged) end condition, for grade of concrete $\left(f_{\mathrm{cu}}=300 \mathrm{~kg} / \mathrm{cm}^{2}\right)$. The highest ratio of the maximum value $\left(\varepsilon_{\mathrm{cl}} / \varepsilon_{\mathrm{cc}}\right)$ was obtained at (hinged-hinged) end condition for grade of concrete $\left(f_{\mathrm{cu}}\right)=900$ $\mathrm{kg} / \mathrm{cm}^{2}$

5. For columns confined with $0.60 \%$ volumetric ratio with (fixed-fixed), (hingedhinged), (fixed-hinged), (fixed-free) end condition, with grade of concrete 300, 600 , and $900 \mathrm{kglcm}^{2}$ for different cross section (circular, rectangular and square) it was found that: Highest strength ratio $\left(f_{\mathrm{cc}} / f_{\mathrm{cu}}\right)$ was $1.436,1.3$ and 1.236 for square confined columns at(fixed- fixed) end condition, circular confined columns at (hinged-hinged) end condition and rectangular columns respectively. Highest lateral strength ratio $\left(f_{\mathrm{cl}} / f_{\mathrm{cc}}\right) \quad 0.486,0.458$ and 0.354 for circular confined columns at (fixed-fixed) end condition, rectangular confined columns with (hinged-hinged) end condition and square columns (fixed-fixed) end condition respectively. Highest lateral strength ratio $\left(f_{\mathrm{cl}} / f_{\mathrm{cu}}\right)$ was 0.716$), 0.558$ and 0.556 for square confined columns at (hinged- hinged), rectangular with, (fixed-hinged) and circular columns with (fixed-fixed) end condition respectively Highest strains ratio $\left(\varepsilon_{\mathrm{cl}} / \varepsilon_{\mathrm{cc}}\right)$ was $0.98,0.863$ and 0.33 for square confined columns at (hinged- hinged), rectangular confined columns (fixedfixed ) and circular columns at (fixed-free) end condition respectively.

6. The lateral strain ratio $\left(\varepsilon_{\mathrm{c}} / \varepsilon_{\mathrm{cc}}\right)$ is approximately the same value for different volumetric ratios of confinement $(0,1.023 \%, 1.6225 \%, 2.70 \%)$. This means the volumetric ratio of confinement has no effect on changing $\left(\varepsilon_{\mathrm{cl}} / \varepsilon_{\mathrm{cc}}\right)$.

7. For columns confined with $0.60 \%$ volumetric ratio with (fixed-fixed), (hingedhinged), (fixed-hinged), (fixed-free), with grade of concrete $300,600,900 \mathrm{kglcm}^{2}$ for different cross sections (circular, rectangular and square) it was found that the influence of concrete compressive strength $\left(f_{\mathrm{cu}}\right)$ on strength ratio $\left(f_{\mathrm{cc}} / f_{\mathrm{cu}}\right)$ $\left(f_{\mathrm{cl}} / f_{\mathrm{cc}}\right)\left(f_{\mathrm{cl}} / f_{\mathrm{cu}}\right)\left(\varepsilon_{\mathrm{cl}} / \varepsilon_{\mathrm{cc}}\right)$ is as follows: Highest strength ratio $\left(f_{\mathrm{cc}} / f_{\mathrm{cu}}\right)$ was 1.436 , 1.3 and 1.294 for grades of concrete $300 \mathrm{kglcm}^{2}$ at fixed-fixed case, grade of $600 \mathrm{kglcm}^{2}$ at hinged-hinged circular column and grade of $900 \mathrm{kglcm}^{2}$ at fixedhinged circular column respectively. This means that the lower strength $f_{\mathrm{cu}}$, the more effective is the confinement represented by higher strength of strength ratio $\left(f_{\mathrm{cd}} / f_{\mathrm{cu}}\right)$.

Highest strength ratio $\left(f_{\mathrm{cl}} / f_{\mathrm{cc}}\right)$ was $0.486,0.458$ and 0.241 for grade of concrete 600 at fixed-fixed circular column, 300 at hinged-hinged (fixed- hinged) of rectangular column and 900 at hinged-hinged rectangular column. Thus, the lower is the strength the more effective is the confinement strength ratio $\left(f_{\mathrm{cl}} / f_{\mathrm{cc}}\right)$. Highest strength ratio $\left(f_{\mathrm{cl}} / f_{\mathrm{cu}}\right)$ was $0.558,0.556$ and 0.282 for grade 300 at fixed-hinged rectangular column, 600 at (fixed- fixed) circular column and 900 at fixed-hinged rectangular column respectively. So that, confinement is more effective in lower grades of concrete than that in higher grades.

Highest strains ratio $(\varepsilon \mathrm{cl} / \varepsilon \mathrm{cc})$ was $0.98,0.977$ and 0.973 for grade of concrete 900 at hinged-hinged square column, for grade of concrete 600 at (hingedhinged) square column and grade of concrete 300 at hinged-hinged square column respectively. This means that confinement has slight effect on strain ratio $\left(\varepsilon_{\mathrm{cl}} / \varepsilon_{\mathrm{cc}}\right)$. 
8. For columns confined with $0.60 \%$ volumetric ratio with (fixed-fixed), (hingedhinged), (fixed-hinged), (fixed-free), with grades of concrete 300,600, 900 $\mathrm{kg} \mathrm{cm}^{2}$ The effect of different cross sections is as follows:-

- For circular column, the highest ratio of $\left(f_{\mathrm{cc}} / f_{\mathrm{cu}}\right)$ was at (fixed- fixed), and the lowest ratio of $\left(f_{\mathrm{cl}} / f_{\mathrm{cc}}\right)$ was at (fixed- free). The lowest ratio of $\left(f_{\mathrm{cl}} / f_{\mathrm{cu}}\right)$ was at (hinged-hinged) and the highest ratio of $\left(\varepsilon_{\mathrm{c}} / \varepsilon_{\mathrm{cc}}\right)$ was at (hingedhinged).

- For Rectangular column, the highest ratio of increase of $\left(f_{\mathrm{cc}} / f_{\mathrm{cu}}\right)$ was at (fixed-hinged) and the lowest ratio was at (fixed- hinged). The highest ratio of $\left(f_{\mathrm{cl}} / f_{\mathrm{cu}}\right)$ was at (hinged-hinged) and the lowest ratio of $\left(\varepsilon_{\mathrm{cl}} / \varepsilon_{\mathrm{cc}}\right)$ was at (hinged-hinged).

- For square column, the highest ratio of $\left(f_{\mathrm{cc}} / f_{\mathrm{cu}}\right)$ was at (fixed- hinged), the lowest ratio of $\left(f_{\mathrm{cl}} / f_{\mathrm{cc}}\right)$ was at (fixed- free). The highest ratio of $\left(f_{\mathrm{cl}} / f_{\mathrm{cu}}\right)$ was at (hinged-hinged) and the highest ratio of $\left(\varepsilon_{\mathrm{cl}} / \varepsilon_{\mathrm{cc}}\right)$ was at (fixed-fixed).

\section{REFERENCES}

1. ABAQUS, Inc. ABAQUS / CAE 6.5 User's Manual 2000.

2. Abdel-Fattah, H.; and Ahmed, S.H., (1989): "Behavior of Hoop Confined High-Strength Concrete Under Axial and Shear Loads", ACI Structural Journal, Vol. 86, No. 6, Nov.-Dec. pp. 652-659.

3. Ceen-219 (2002): Topics in Reinforced Concrete Consider the column section subjected to axial load and bundling moment at its end in figure R.C.S section with axial load/www.eng.mu.edu. foleyc/courses/ceon-219 axial and bending pdf-3458K.

4. J. Xie, James G. MacGregor and A.E. Elwi (1996): "Numerical Investigation of Eccentrically loaded High-Strength Concrete Tied Columns". ACI Structural Journal, Vol. 93, No. 4, pp. 449-461.

5. Khairy Hasan A. (2003): "Finite Element Study on Shear Behavior of RCDeams with High Strength Concrete", $1^{\text {st }}$ International conference of Civil Engineering, Oct., Assiut, Egypt. pp. 835-845.

6. Khairy Hassan A. (1999): "Analytical Study on Seismic Resistant Characteristics of RC Bridge Piers" Thesis for Doctor of Engineering Degree, Saitama University, Japan.

7. Li Bing, R. Park, and H. Tanak (2001): "Stress-Strain Behavior of HighStrength Concrete Confined by Ultra-High-and Normal-Strength Transverse Reinforcements", ACI Structural Journal, Vol. 98, No. 3, pp. 395-406.

8. Mander, J.B.; Priestely, M.N. and Park, R. (1988): Theoretical StressStrain Model for Confined Concrete", J.Structural Engineering, AS CE Vol.114, No. 8.

9. Natelie Ann Lloyd and B. Vijaya Rangan (1996): "Studies on HighStrength Concrete Columns Under Eccentric Compression", ACI Structural Journal, Vol. 93, No. 6; pp. 631-638.

10. Polat, M.B. (1992): "Behavior of Normal and High Strength Concrete Under Axial Compression", M.Sc. Thesis, Department of Civil Engineering, University of Toronto, Ontairo, Canada, pp. 37-50. 
11. Salim R. Razvi and Murat Saatcioglu (1994): “ACI Structural” Journal, Vopl. 91, No. 6, pp. 678-687.

12. Salim R. Razvi and Murat Saatcioglu (1999): "Circular High - Strength Concrete Columns Under Concentric Compression", ACI Str. J., Vol. 96, No. 5, pp. 817-825.

13. Stephen, J. Faster (2001): "On Behavior of High-Strength Concrete columns Cover Spalling, Steel Fibers, and Ductility", ACI Structural Journal, Vol. 98, No. 4, 583-589.

14. Sugano, S.T.; Kimura, H.; Tamura, A. and Ichikawa, A. (1990): "Experimental Studies on Seismic Behavior of Reinforced Concrete Members of High-Strength Concrete", High-Strength Concrete, Second International Syroposium, Sp. 121-5, ACI International, pp. 61-87.

15. Watanabe, F.; Muguruma, H.; Matsutani, T.; and Sanda, D. (1987): "Utilization of High-Strength Concrete for Reinforced Concrete High-Rise Buildings in Seismic Area", Utilization of High Strength Concrete Proceedings Stavanger, Norway, Tapir Publishers, pp. 665-666.

\section{بعض العوامل التي تؤثر على السلوك الاستاتيكي للأعمدة الخرسانية المسلحة

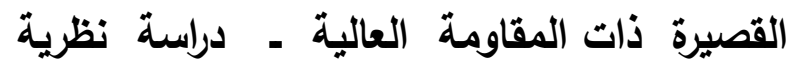

تم في هذا البحث عمل دراسة نظرية لبيان العوامل المؤثرة علي السلوك الأستاتيكي المحوري للأعمدة

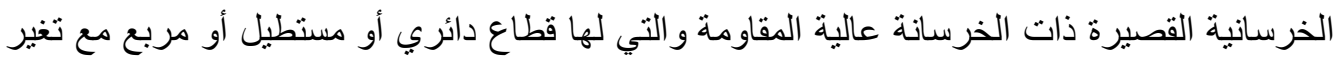

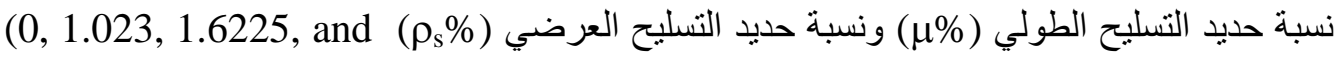

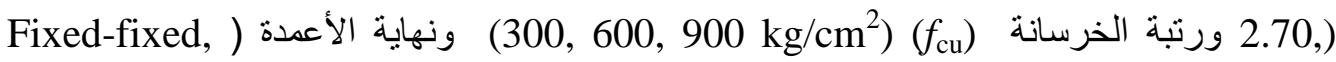
(Fixed-hinged, Hinged-hinged, Fixed-free

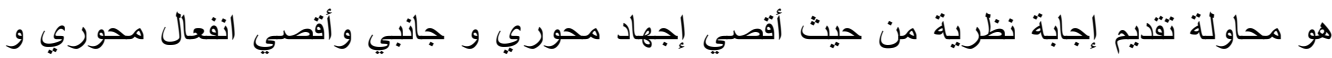

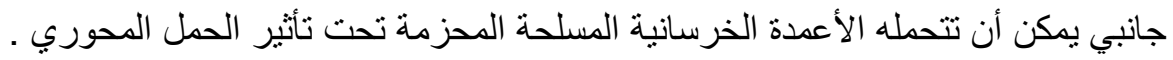

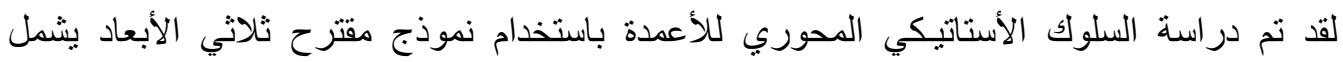

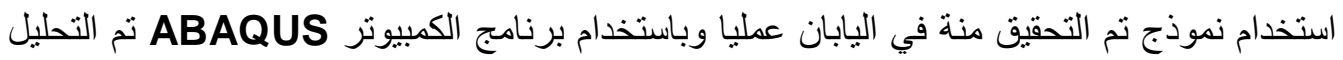

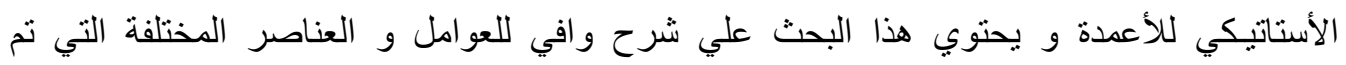
استخدامها في هذا البرنامج لحساب أقصي إجهادات

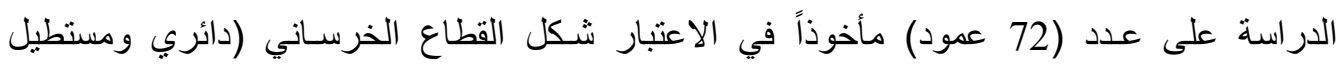

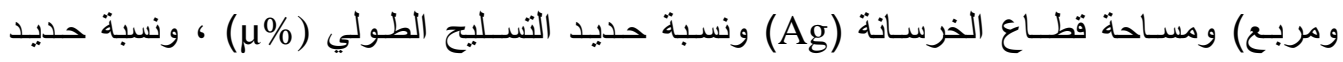

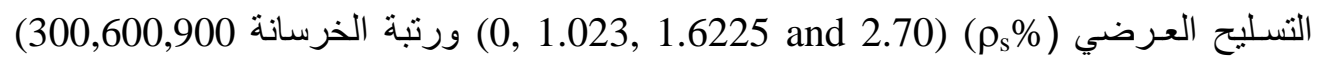

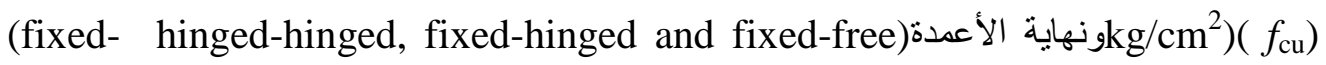
وذللك برسم العلاقات بين العوامل الآتية : الإجهاد المحوري (fixed 


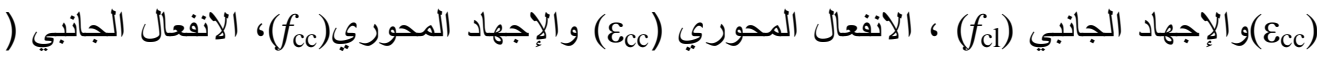

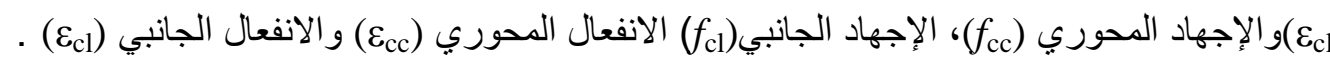

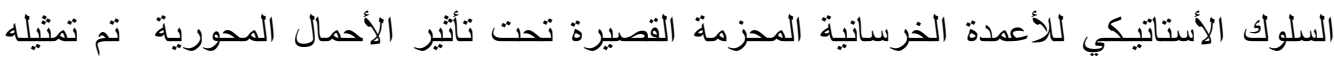

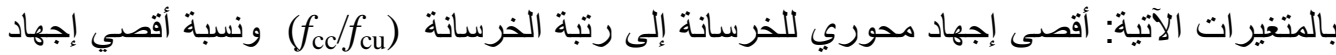
جانبي للخرسانة إلى أقصي إجهاد محوري للخرسانة رتبة الخرسانة $\left(f_{\text {cl }} / f_{\text {cu }}\right.$ ونسبة أقصي انفعال جانبي للخرسانة إلى أقصي انفعال محوري للخرسانة . $\left(\varepsilon_{\mathrm{cl}} / \varepsilon_{\mathrm{cc}}\right)$ أثثتت الدراسة أن هذه المتغيرات تتأثر بدرجة كبيرة بالعوامل التي شملتها الدراسة والسابق ذكرها

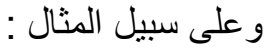

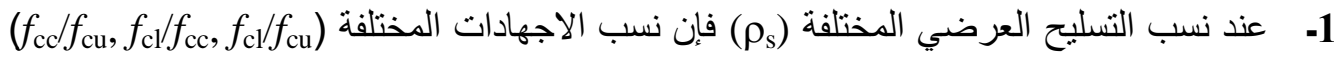
تزيد مع زيادة نسب التحزيم للعمود الخرساني (م) ) ، وأعلى نسب مقاومة نتحقق عند القطاع

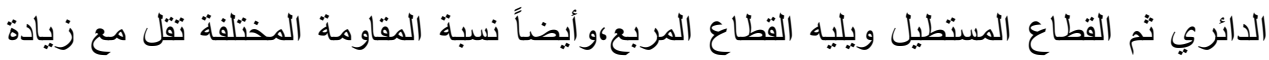

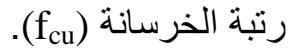

2- عند نهايات الأعمدة المختلفة نسب الاجهادات العامود المربع عند نهاية (fixed-fixed) لرتبة الخرسانة (C300) ، ويليه القطاع للعمود الدائري ، ثم القطاع للعمود المستطيل ، وكلاهما عند نهاية (hinged-hinged) لرتبة الخرسانة 